\title{
A bibliometric analysis to illustrate the role of an embedded research capability in South African National Parks
}

\author{
Brian W. van Wilgen ${ }^{1}$ (D) Nelius Boshoff ${ }^{2} \cdot$ Izak P. J. Smit $^{3,4}$ • \\ Sofia Solano-Fernandez ${ }^{5}$ Luanita van der Walt ${ }^{6}$
}

Received: 8 September 2015/Published online: 15 February 2016

(C) Akadémiai Kiadó, Budapest, Hungary 2016

\begin{abstract}
We conducted a bibliometric analysis of research in or about South African National Parks, published between 2003 and 2013. Our goal was to identify the major research topics, and to examine the role of in-house ("embedded") researchers in producing relevant knowledge and in leveraging additional benefits through collaboration with external researchers. The authorship of 1026 papers was highly collaborative, with the majority of papers $(70 \%)$ being contributed by external researchers. Research was concentrated in five of the 19 parks, and was biased towards animal and ecological process studies in savanna ecosystems. Researchers have mainly worked in older, larger, and
\end{abstract}

Brian W. van Wilgen

bvanwilgen@sun.ac.za

Nelius Boshoff

scb@sun.ac.za

Izak P. J. Smit

izak.smit@sanparks.org

Sofia Solano-Fernandez sofisolano22@gmail.com

Luanita van der Walt lvdwalt1@csir.co.za

1 Centre for Invasion Biology, Department of Botany and Zoology, Stellenbosch University, Private Bag X1, Matieland 7602, South Africa

2 Centre for Research on Evaluation, Science and Technology and DST/NRF CoE in Scientometrics and Science, Technology and Innovation Policy, Stellenbosch University, Private Bag X1, Matieland 7602, South Africa

3 Scientific Services, Kruger National Park, South African National Parks, Private Bag X402, Skukuza 1350, South Africa

4 Centre for African Ecology, School of Animal, Plant and Environmental Sciences, University of the Witwatersrand, Private Bag 3, Wits 2050, South Africa

5 P.O. Box 321, Skukuza 1350, South Africa

6 CSIR Consulting and Analytical Services, P.O. Box 320, Stellenbosch 7600, South Africa 
arguably more aesthetically-appealing parks that are either close to hand or that provide subsidized accommodation to researchers, and that have established experimental setups or useful long-term data; smaller and more remote parks have received less research attention. Certain priority topics for management, such as degradation of freshwater ecosystems, global change, marine ecology, and socio-ecological dynamics have not received much attention, and are areas identified for growth. Embedded authors were found to be more highly connected and influential than external researchers, leveraging and connecting many research projects. We conclude that there are significant benefits to be gained for the management of protected areas through the maintenance of an embedded research capability.

Keywords Citation rates - Disease $\cdot$ Fire $\cdot$ Invasive alien species $\cdot$ Mammals $\cdot$ Research collaboration

\section{Introduction}

The establishment and scientific management of a network of protected areas is one of the strategies for conserving the world's natural ecosystems. Protected areas can also serve as research laboratories, where ecosystem processes can be studied in relatively undisturbed environments, thus providing a benchmark against which change in unprotected, disturbed or transformed areas can be assessed. The management of protected areas seeks to prevent the degradation of natural ecosystems and the loss of species in the face of many threats, including invasion by alien species, illegal resource use and poaching, and altered fire and hydrological regimes. For example, it has been estimated that protected areas have kept the extinction rates of mammals, birds and amphibians $20 \%$ lower than would have been the case without these refuges (Hoffmann et al. 2010). It is frequently suggested that conservation management practices should be informed by the best available evidence, and the generation of evidence in turn requires ongoing research (Adams and Sandbrook 2013).

Several organizations responsible for the management of a network of protected areas maintain an in-house research capability. Scientists working for conservation agencies within protected areas are expected to conduct research that is robust and dependable, aligned to the achievement of conservation goals, and relevant to managers (Roux et al. 2015). These "embedded" scientists are more likely to be able to influence management, as they are aware of research needs of management, and are enmeshed in the culture and operations of the organization. In this capacity, they gain insights into the constraints and initiatives of their management colleagues by building relationships, sharing ideas, and collaborating informally or formally (Jenkins et al. 2012). In addition, embedded researchers can improve their productivity through active collaboration with external researchers, and even in cases where there is no formal collaboration, embedded researchers can influence external researchers during the process of reviewing project proposals. Embedded researchers also facilitate access and support to external researchers who wish to work in protected areas. It is important to facilitate access to national parks for external scientists, both to increase overall research productivity and to further increase understanding among in-house researchers. As such, embedded researchers can be seen as bridging agents, with an important two-way role to play in translating and 
repackaging needs and knowledge between field practitioners and scientists (Sunderland et al. 2009).

Here we report on a bibliometric analysis of papers based on research in or about South African National Parks, and published over 11 years. Our intent was to examine two issues. First, we wished to identify the topics that were addressed, and the extent to which National Parks served as open-air research laboratories in which understanding of these topics could be studied in relatively undisturbed environments. Secondly, we examined the role of in-house researchers employed by South African National Parks and the Department of Agriculture in the case of some veterinarians living and working in Kruger National Park (hereafter "embedded researchers") in producing a body of knowledge that could be used to improve management, both with and without the collaboration of external researchers.

\section{Methods}

\section{Identification of research papers}

South Africa has a network of 19 National Parks, ranging in size from 2000 to 2,000,000 ha. The responsibilities for research in individual parks are divided between three inhouse research centres (Savanna and Arid, Cape, and Garden Route; Table 1). We identified all peer-reviewed papers (excluding book chapters) published between 2003 and 2013 that were based on research carried out in one or more of these parks, or relevant to the ecology and management of a park or parks. The papers were identified by searching Google Scholar using keywords that included the names of individual parks (or variants of these names where they had changed over time), or the use of both "National Park" and "South Africa" in the paper. We also searched for papers listing any of the embedded researchers as authors, but excluded any papers by these authors if they did not arise from work in a National Park. Lists were checked against the National Parks Annual Research Reports (available for 2012 and 2013 only), and by asking embedded researchers to check the list for completeness. Papers were also included in our analysis if they reported studies beyond the boundaries of National Parks, provided that a National Park contributed to the study (for example comparisons between National Parks and adjacent unprotected areas; or studies where at least some of the data were collected in National Parks).

\section{Classification of research papers}

Copies of all papers were obtained, and information pertaining to each paper was assembled in a database. Information on the database included a unique identifier for individual authors, their affiliations, and the park in which the research was conducted (if the paper covered more than one park, it was assigned to a category for "several parks"). We examined each paper in enough detail to be able to assign it to an ecosystem type. Ecosystem types included the major terrestrial biomes of South Africa (savanna, fynbos, thicket, grassland, karoo, and forest), and aquatic biomes (marine, freshwater and estuarine). If the paper covered more than one ecosystem, it was assigned to all of the ecosystem types relevant to the paper. During examination of the papers, we identified ten broad categories of research (Table 2), and classified papers in terms of these categories 
Table 1 Salient features of South African National Parks

\begin{tabular}{|c|c|c|c|c|}
\hline National Park & Area (ha) & $\begin{array}{l}\text { Date } \\
\text { proclaimed }\end{array}$ & $\begin{array}{l}\text { Centre responsible } \\
\text { for research }\end{array}$ & $\begin{array}{l}\text { Ecosystem types } \\
\text { represented }\end{array}$ \\
\hline Addo Elephant & 163,297 & $1931^{\mathrm{a}}$ & Garden Route & $\begin{array}{l}\text { Thicket, fynbos, karoo, marine, } \\
\text { freshwater (rivers) }\end{array}$ \\
\hline Agulhas & 20,415 & 1999 & Cape & Fynbos, estuarine, marine \\
\hline Augrabies Falls & 58,699 & 1966 & Savanna and Arid & Karoo \\
\hline Bontebok & 2432 & 1961 & Cape & Fynbos \\
\hline Camdeboo & 18,946 & 2005 & Savanna and Arid & Karoo \\
\hline Garden Route & 137,796 & $2009^{\mathrm{b}}$ & Garden Route & $\begin{array}{l}\text { Fynbos, forest, estuarine, } \\
\text { marine }\end{array}$ \\
\hline Golden Gate & 34,062 & 1963 & Savanna and Arid & Grassland \\
\hline $\begin{array}{l}\text { Kalahari } \\
\text { Gemsbok }\end{array}$ & 960,029 & 1931 & Savanna and Arid & Savanna \\
\hline Karoo & 84,082 & 1979 & Savanna and Arid & Karoo \\
\hline Kruger & $1,962,362$ & 1926 & Savanna and Arid & Savanna, freshwater (rivers) \\
\hline Mapungubwe & 15,311 & 1998 & Savanna and Arid & Savanna, freshwater (rivers) \\
\hline Marakele & 60,865 & 1994 & Savanna and Arid & Savanna \\
\hline Mokala & 25,902 & 2007 & Savanna and Arid & Savanna \\
\hline Mountain Zebra & 27,900 & 1937 & Savanna and Arid & Karoo \\
\hline Namaqua & 130,641 & 2001 & Cape & Karoo, marine \\
\hline Richtersveld & 162,445 & 1991 & Savanna and Arid & Karoo, freshwater (rivers) \\
\hline Table Mountain & 33,010 & 1998 & Cape & Fynbos, estuarine, marine \\
\hline Tankwa Karoo & 138,570 & 1986 & Cape & Karoo \\
\hline West Coast & 47,026 & 1985 & Cape & Fynbos, marine \\
\hline
\end{tabular}

\footnotetext{
a Substantially expanded in 1995 to include additional land and a marine component

b A smaller portion of the Garden Route National Park was proclaimed as the Tsitsikamma National Park in 1964
}

(papers that addressed more than one category of research were classified under two or more categories). Papers were then further classified by sub-categories, based on the major focus of the work (Table 2).

\section{Mapping of research topics}

We used VOSviewer (version 1.5.2; http://www.vosviewer.com/) to identify and map the primary research topics discussed in the papers, based on the co-occurrence of words in the titles and abstracts of papers. A text corpus from the Web of Science (WoS) was used to create the co-occurrence maps, and consequently we were only able to do this for papers published in journals recognised by WoS (853 out of the 1026 papers in our sample). This enabled the visualization (van Eck and Waltman 2010) of research topics and relationships in the data set as a whole, and within subsets of the data. A threshold of 10 occurrences of a term was applied. 
Table 2 Classification of research papers by categories and subcategories

\begin{tabular}{|c|c|c|}
\hline Category of research & Description & Subcategories \\
\hline $\begin{array}{l}\text { Ecosystem processes (other } \\
\text { than threatening processes, } \\
\text { see below) }\end{array}$ & $\begin{array}{l}\text { Papers that report on fundamental } \\
\text { ecological processes, but not on } \\
\text { threatening processes (see below) }\end{array}$ & $\begin{array}{l}\text { Nutrient cycling and } \\
\text { biogeochemistry } \\
\text { Biomass dynamics } \\
\text { Competition } \\
\text { Pollination } \\
\text { Plant physiology } \\
\text { Animal-water relations } \\
\text { Parasitism } \\
\text { Fire } \\
\text { Predator-prey relationships } \\
\text { Plant-animal interactions and } \\
\text { herbivory } \\
\text { Diseases }\end{array}$ \\
\hline Climate & $\begin{array}{l}\text { Papers that report on climate trends, } \\
\text { or that use climatic data as the } \\
\text { main focus of the study }\end{array}$ & $\begin{array}{l}\text { Rainfall } \\
\text { Drought } \\
\text { Floods } \\
\text { Climate change }\end{array}$ \\
\hline Animals & $\begin{array}{l}\text { Papers that report on the distribution, } \\
\text { status, ecology or management of } \\
\text { particular species or groups of } \\
\text { animals }\end{array}$ & $\begin{array}{l}\text { Mammals } \\
\text { Birds } \\
\text { Reptiles } \\
\text { Fish } \\
\text { Amphibians } \\
\text { Insects } \\
\text { Aquatic (estuarine) invertebrates } \\
\text { Terrestrial invertebrates other than } \\
\text { insects, and microbial organisms } \\
\text { Aquatic (freshwater) invertebrates } \\
\text { Marine invertebrates }\end{array}$ \\
\hline Plants & $\begin{array}{l}\text { Papers that report on the distribution, } \\
\text { status, ecology or management of } \\
\text { particular species or groups of } \\
\text { plants }\end{array}$ & $\begin{array}{l}\text { Trees } \\
\text { Grasses } \\
\text { Shrubs } \\
\text { Non-grass herbaceous } \\
\text { Fungi } \\
\text { Succulents } \\
\text { Aquatic plants } \\
\text { Marine plants } \\
\text { Vegetation studies }\end{array}$ \\
\hline Abiotic & $\begin{array}{l}\text { Papers that report on abiotic aspects } \\
\text { of the ecosystem }\end{array}$ & $\begin{array}{l}\text { Geology } \\
\text { Soil } \\
\text { Geomorphology } \\
\text { Atmosphere } \\
\text { Water }\end{array}$ \\
\hline
\end{tabular}


Table 2 continued

\begin{tabular}{|c|c|c|}
\hline Category of research & Description & Subcategories \\
\hline Threatening processes & $\begin{array}{l}\text { Papers that report on threatening } \\
\text { processes }\end{array}$ & $\begin{array}{l}\text { Invasive alien species } \\
\text { Habitat loss and degradation } \\
\text { Exploitation of resources } \\
\text { Diseases and parasites } \\
\text { Climate change }\end{array}$ \\
\hline Palaeontology & $\begin{array}{l}\text { Papers reporting palaeontological } \\
\text { studies }\end{array}$ & None \\
\hline Social & $\begin{array}{l}\text { Papers that report predominantly on } \\
\text { the human dimensions affecting, or } \\
\text { affected by, National Parks }\end{array}$ & $\begin{array}{l}\text { History } \\
\text { Archaeology } \\
\text { Exploitation of resources } \\
\text { Socio-economic benefits } \\
\text { Conflicts } \\
\text { Tourism and visitor perceptions } \\
\text { Stakeholder processes and social } \\
\text { learning } \\
\text { Environmental education and } \\
\text { outreach } \\
\text { Political issues }\end{array}$ \\
\hline Management & $\begin{array}{l}\text { Papers that have clear management } \\
\text { recommendations or evaluations }\end{array}$ & $\begin{array}{l}\text { Design of management and } \\
\text { conservation policies } \\
\text { Design of management and } \\
\text { conservation systems } \\
\text { Monitoring and evaluation of } \\
\text { management practices } \\
\text { Monitoring of populations (census, } \\
\text { game counts) }\end{array}$ \\
\hline Methodological studies & $\begin{array}{l}\text { Papers that report on the } \\
\text { development or testing of methods } \\
\text { of study }\end{array}$ & $\begin{array}{l}\text { Remote sensing } \\
\text { GIS } \\
\text { Modelling } \\
\text { Survey techniques }\end{array}$ \\
\hline
\end{tabular}

\section{Effect of authorship on citation frequency}

We used citations to illustrate the scientific impact of publications about South African National Parks by different combinations of authors. We selected all papers classified on the WoS as either articles or reviews, and used the WoS raw data from Thomson Reuters, housed at the Centre for Research on Evaluation, Science and Technology at Stellenbosch University, for the citation analysis. We used the data as available at the end of 2013. The papers were categorised in terms of the number of authors (single-author or multi-author papers), and the origin of authors (including or excluding international authors, and including or excluding embedded researchers). Since citation analysis requires a citation window of at least 1 year, we only took papers dated 2012 or earlier into account. This left 
a total of 722 valid papers for the citation analysis. The citation analysis was performed with and without self-citations (self-citation occurs if the citing paper and the cited paper have at least one author name in common). We examined both all citations over the lifetime of the paper, and 2-year citation windows (where the number of citations was limited to the first 2 years after publication). The year 2012 was excluded from the 2-year citation analysis as citation records were available only until 2013. This left a total of 597 papers for the 2-year window analysis.

\section{Role of embedded versus external researchers}

We compared the role of embedded and external researchers by calculating two centrality metrics for individual authors, and comparing means for embedded and external researchers separately (Lui et al. 2005). Degree centrality simply measures the number of connections that tie authors to their co-authors in the publication data set. Betweenness centrality measures how often a particular author is found on the shortest path between papers in the publication data set. Authors with high betweenness scores are those who control the flow of information between nodes (papers) in the dataset. We hypothesized that embedded researchers would be more likely to be more highly connected and influential than external researchers, as measured by the degree and betweenness measures of centrality, thus supporting the notion that they play a facilitating role in research.

\section{Results}

\section{Authorship of papers}

We identified 1026 papers published between 2003 and 2013 (Fig. 1). The research reported in published papers showed a high degree of collaboration between researchers from many organizations. A total of 2003 authors from 578 organizations contributed to the 1026 published papers, with a mean of 3.8 authors per paper across all papers. For papers that included embedded researchers as authors, the mean number of authors per paper was higher (5) than for papers that did not include an embedded author (3.3). Just under one third $(30 \%)$ of the papers included at least one embedded author, of which most (26 out of the $30 \%$ ) also included an external author or authors; $70 \%$ of papers published had no co-authorship by an embedded author. Papers written by a single author were rare (10\% of papers), and half of the multi-authored papers included an international collaborator (Fig. 2). Most (87\%) of the papers had at least one South African author, with authors from the United States (20\% of papers), the United Kingdom (10\% of papers), Germany ( $7 \%$ of papers), Australia (5\% of papers), and the rest of Africa (4\% of papers) also making contributions. Not surprisingly, embedded researchers constituted the largest single source of authors $(30 \%)$ to papers, with substantial contributions ( $>10 \%$ of all papers) coming from the South African Universities of Pretoria, Cape Town and Stellenbosch, and internationally from the Universities of California (USA) and Oxford (UK) (Fig. 3).

A relatively small number of authors made a disproportionate contribution to the published output over the period examined. The authors listed in Table 3 made up $2 \%$ of all authors, but contributed to $31 \%$ of the papers (counts in Table 3 are not unique paper 


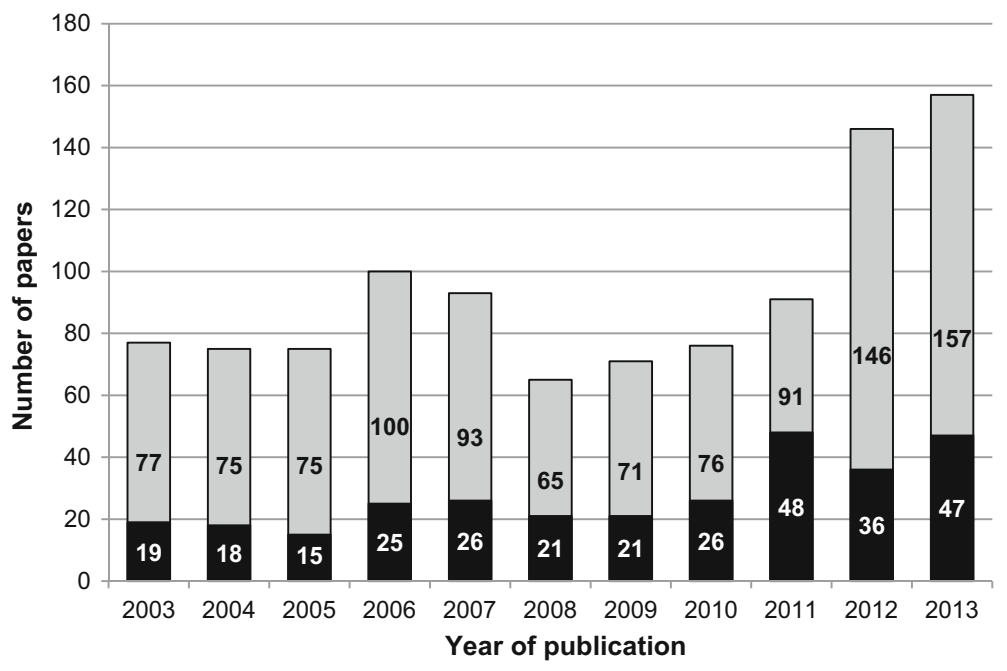

Fig. 1 The number of papers based on research in or about South African National Parks published between 2003 and 2013 (grey plus black shading), with a subset of papers co-authored by embedded researchers (black shading)

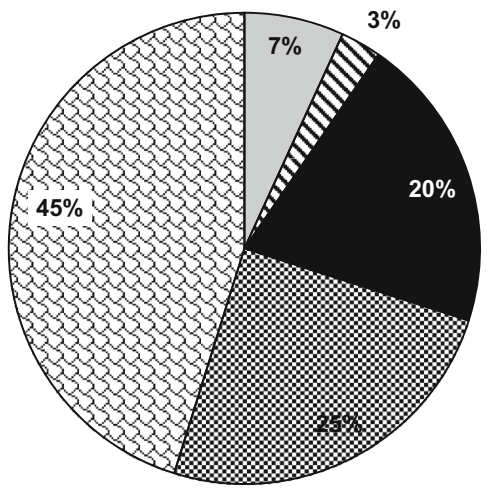

Papers with a single South African author

\ Papers with a single international author

Multi-authored papers with South African authors at one institution

Q Multi-authored papers with South African authors at multiple institutions

Multi-authored papers with at least one international author

Fig. 2 Authorship of papers based on research in or about South African National Parks published between 2003 and 2013

counts, given that some of the authors collaborated on the same paper). Of these authors, nine were embedded researchers, nine were external South African researchers and four were international collaborators.

\section{Distribution of research across parks and ecosystem types}

A large majority (85\%) of all papers arose from research conducted in only five of the 19 parks (Kruger, Garden Route, Table Mountain, Addo Elephant and Kalahari Gemsbok), with more than half (54\%) of all papers being from the Kruger National Park (Fig. 4). Most (59\%) papers reported on research in savanna ecosystems, with between 8 and $12 \%$ of papers reporting respectively on research in fynbos, karoo and marine ecosystem types. 


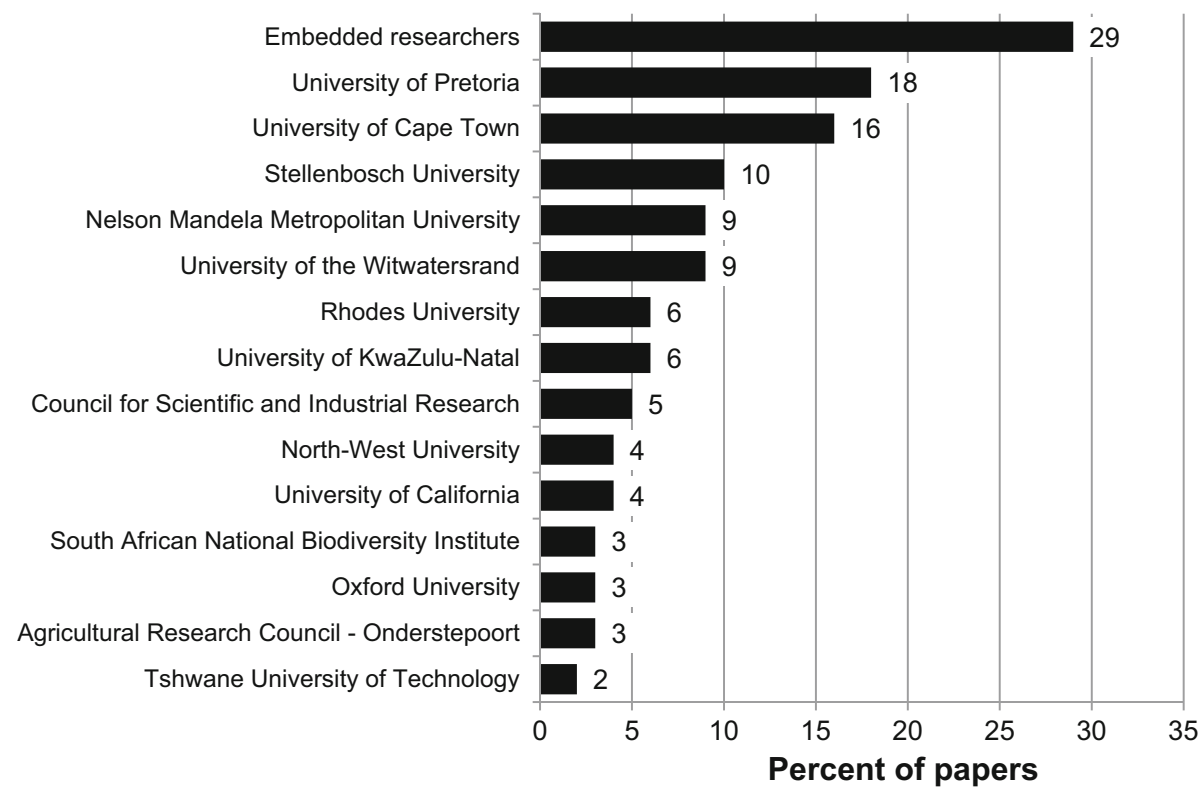

Fig. 3 The relative contribution (\% of all papers, $n=1026$ ) of research organizations to the authorship of individual papers based on research in or about South African National Parks published between 2003 and 2013

Surprisingly (given their importance and vulnerability), freshwater ecosystems were poorly researched, with only $5 \%$ of all papers addressing this ecosystem type (Fig. 5). The VOSviewer map created for all papers in savanna ecosystems forms four distinct clusters of issues (Fig. 6). These are (1) management-related papers (top right, blue cluster); (2) research related to the ecology and dynamics of savanna ecosystems, including interactions between fire, herbivory and vegetation structure and composition at a range of scales (bottom right, red cluster); (3) animal populations, including predator-prey relationships, and mortality and declines in populations of certain species (bottom left, green cluster); and (4) disease in African buffaloes (Syncerus cafer) (top left, yellow cluster).

\section{Issues addressed in research}

Our analysis has revealed that research in South African National Parks has had a strong focus on animals and ecological processes in terrestrial ecosystems, mainly savannas, and that most of this research has been conducted in the Kruger National Park, supplemented by research in the Addo Elephant and Kalahari Gemsbok parks. Together, these three parks accounted for $68 \%$ of the published papers, in which accounts of the ecology and management of large mammals dominated. It is perhaps not surprising to find this bias. Large, charismatic or iconic megafauna are appealing subjects for research, and protected areas such as National Parks are rapidly becoming the only places where significant wild populations survive, and can be studied. In addition, managers of protected areas often focus their attention on such species as they are conspicuous, ecologically significant, and disproportionately important in terms of tourism appeal, and thus income generation (Walpole 
Table 3 The 22 authors responsible for the largest share of papers published between 2003 and 2013 , reporting research in South African National Parks

\begin{tabular}{|c|c|c|c|c|}
\hline Author & $\begin{array}{l}\text { Number } \\
\text { of } \\
\text { papers }\end{array}$ & Focus of research & $\begin{array}{l}\text { Park(s) in which } \\
\text { research was } \\
\text { carried out }\end{array}$ & Affiliation \\
\hline Grant, C.C. & 36 & $\begin{array}{l}\text { Plant-animal interactions and nutrient } \\
\text { cycling in savanna ecosystems }\end{array}$ & Kruger & $\begin{array}{l}\text { Embedded } \\
\text { researcher }\end{array}$ \\
\hline $\begin{array}{l}\text { Kerley, } \\
\text { G.I.H. }\end{array}$ & 31 & Large mammal ecology & Addo Elephant & $\begin{array}{l}\text { South African } \\
\text { academic }\end{array}$ \\
\hline $\begin{array}{l}\text { Foxcroft, } \\
\text { L.C. }\end{array}$ & 29 & Invasive alien species & Kruger & $\begin{array}{l}\text { Embedded } \\
\text { researcher }\end{array}$ \\
\hline $\begin{array}{l}\text { Mills, } \\
\text { M.G.L. }\end{array}$ & 24 & Large mammalian carnivores & $\begin{array}{l}\text { Kruger } \\
\text { Kalahari- } \\
\text { Gemsbok }\end{array}$ & $\begin{array}{l}\text { Embedded } \\
\text { researcher }\end{array}$ \\
\hline $\begin{array}{l}\text { Ferreira, } \\
\text { S.M. }\end{array}$ & 23 & Large mammal ecology & Kruger & $\begin{array}{l}\text { Embedded } \\
\text { researcher }\end{array}$ \\
\hline Govender, N. & 23 & $\begin{array}{l}\text { Fire ecology and management in } \\
\text { savanna ecosystems }\end{array}$ & Kruger & $\begin{array}{l}\text { Embedded } \\
\text { researcher }\end{array}$ \\
\hline $\begin{array}{l}\text { Owen-Smith, } \\
\text { N. }\end{array}$ & 23 & Large mammal ecology & Kruger & $\begin{array}{l}\text { South African } \\
\text { academic }\end{array}$ \\
\hline Biggs, H.C. & 21 & Complexity and adaptive management & Kruger & $\begin{array}{l}\text { Embedded } \\
\text { researcher }\end{array}$ \\
\hline Smit, I.P.J. & 21 & Savanna ecology, remote sensing & Kruger & $\begin{array}{l}\text { Embedded } \\
\text { researcher }\end{array}$ \\
\hline Saayman, M. & 20 & $\begin{array}{l}\text { Social and economic aspects of } \\
\text { tourism }\end{array}$ & $\begin{array}{l}\text { Kruger } \\
\text { Kalahari } \\
\quad \text { Gemsbok } \\
\text { Addo Elephant } \\
\text { Garden Route } \\
\text { Karoo } \\
\text { Table Mountain }\end{array}$ & $\begin{array}{l}\text { South African } \\
\text { academic }\end{array}$ \\
\hline Slotow, R. & 18 & Large mammal ecology & $\begin{array}{l}\text { Kruger } \\
\text { Mapungubwe }\end{array}$ & $\begin{array}{l}\text { South African } \\
\text { academic }\end{array}$ \\
\hline $\begin{array}{l}\text { van Wilgen, } \\
\text { B.W. }\end{array}$ & 18 & $\begin{array}{l}\text { Fire ecology and management in } \\
\text { savanna and fynbos ecosystems; } \\
\text { invasive alien species }\end{array}$ & $\begin{array}{l}\text { Kruger } \\
\text { Table Mountain } \\
\text { Garden Route }\end{array}$ & $\begin{array}{l}\text { South African } \\
\text { academic }\end{array}$ \\
\hline Bengis, R.G. & 17 & Veterinary and disease research & Kruger & $\begin{array}{l}\text { Embedded } \\
\text { researcher }\end{array}$ \\
\hline Bond, W.J. & 17 & Fire ecology in savanna ecosystems & Kruger & $\begin{array}{l}\text { South African } \\
\text { academic }\end{array}$ \\
\hline Hofmeyr, M. & 17 & Veterinary and disease research & Kruger & $\begin{array}{l}\text { Embedded } \\
\text { researcher }\end{array}$ \\
\hline $\begin{array}{l}\text { Lee-Thorp, } \\
\text { J.A. }\end{array}$ & 17 & Paleo-anthropology & Kruger & $\begin{array}{l}\text { International } \\
\text { academic }\end{array}$ \\
\hline Prins, H.H.T. & 17 & Savanna ecology & Kruger & $\begin{array}{l}\text { International } \\
\text { academic }\end{array}$ \\
\hline $\begin{array}{l}\text { Richardson, } \\
\text { D.M. }\end{array}$ & 17 & Invasive alien species & Kruger & $\begin{array}{c}\text { South African } \\
\text { academic }\end{array}$ \\
\hline $\begin{array}{l}\text { Sponheimer, } \\
\text { M. }\end{array}$ & 17 & Paleo-ecology; carbon isotopes & Kruger & $\begin{array}{l}\text { International } \\
\text { academic }\end{array}$ \\
\hline Asner, G.P. & 16 & $\begin{array}{l}\text { Remote sensing; spatial ecology of } \\
\text { savannas }\end{array}$ & Kruger & $\begin{array}{l}\text { International } \\
\text { academic }\end{array}$ \\
\hline
\end{tabular}


Table 3 continued

\begin{tabular}{lllll}
\hline Author & $\begin{array}{l}\text { Number } \\
\text { of } \\
\text { papers }\end{array}$ & Focus of research & $\begin{array}{l}\text { Park(s) in which } \\
\text { research was } \\
\text { carried out }\end{array}$ & Affiliation \\
\hline Du Toit, J.T. & 16 & Large mammal ecology & $\begin{array}{l}\text { Kruger } \\
\text { Kalahari } \\
\text { Gemsbok }\end{array}$ & $\begin{array}{c}\text { South African and } \\
\text { international } \\
\text { academic }\end{array}$ \\
$\begin{array}{l}\text { Hayward, } \\
\text { M.W. }\end{array}$ & 16 & Large mammalian carnivores & Addo Elephant & $\begin{array}{c}\text { South African and } \\
\text { international } \\
\text { academic }\end{array}$ \\
\hline
\end{tabular}

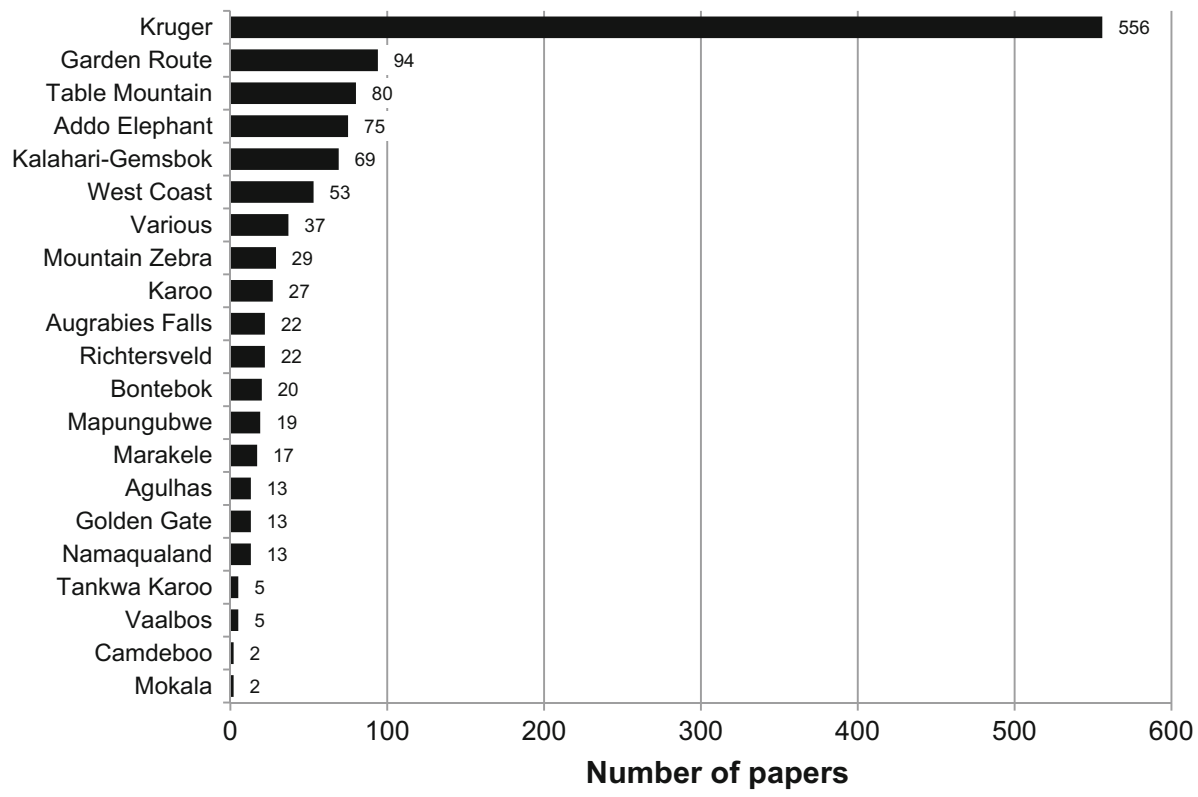

Fig. 4 The contribution of individual South African National Parks to the number of papers published between 2003 and 2013

and Leader-Williams 2002). Researchers who work on these species also seem to be more successful in attracting research funding (Leader-Williams and Dublin 2000).

The five parks in the fynbos (Mediterranean-climate shrubland) biome (Garden Route, Table Mountain, West Coast, Bontebok and Agulhas, four of which include a substantial marine component) accounted for a further $25 \%$ of all papers published. Again, studies on animals dominated this research, accounting for more than half $(52 \%)$ of the papers. However, in contrast to the savanna parks, animal-related research investigated marine animals and birds, rather than large terrestrial mammals. In the fynbos parks, papers on management, fire, and invasive alien species also featured prominently.

The VOSviewer map created for all papers across all parks in WoS forms four distinct clusters of issues (Fig. 7). These are (1) papers reporting on the ecology of savanna ecosystems, including the dynamics of trees and grasses in the vegetation, the effects of 


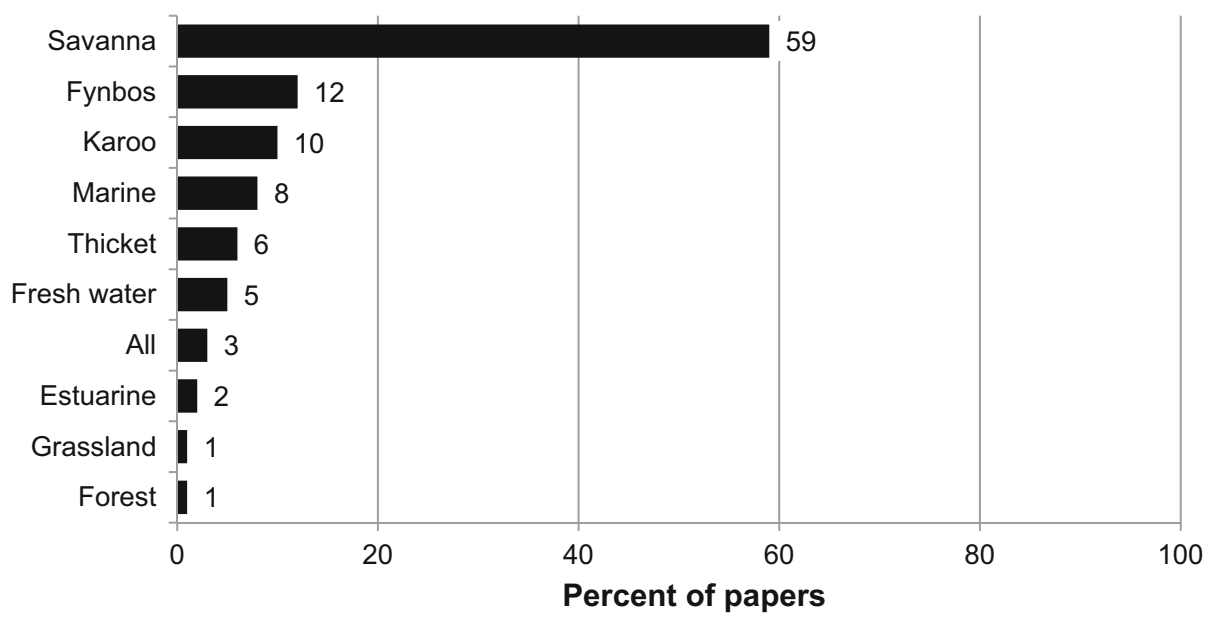

Fig. 5 The distribution across ecosystem types of papers $(n=1026)$ based on research in or about South African National Parks published between 2003 and 2013

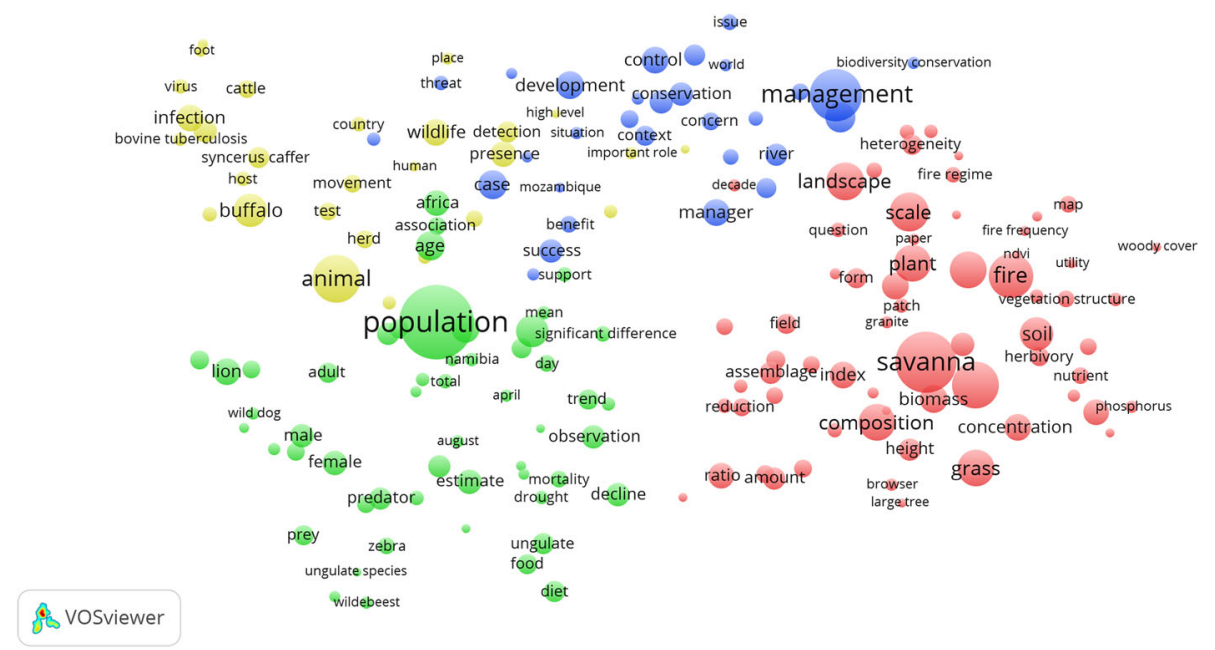

Fig. 6 Visualization of research clusters and topics based on the frequency of words in the titles and abstracts of 512 papers reporting research in savanna ecosystems

fire, and the influence of herbivory and key herbivores such as elephants (Loxodonta africana) (top right, green cluster); (2) management-related research, where the tension between conservation and development, and the development of indicators, monitoring, and adaptive management were studied (bottom left, red cluster); (3) animal-related research, which is also the largest single category with almost half (49\%) of all papers (right-hand, yellow cluster); and (4) non-savanna research, including estuarine, coastal and fish studies (central blue cluster). More than half $(56 \%)$ of the animal-related papers reported research about mammals, including African buffaloes, lions (Panthera leo), wild dogs (Lycaon pictus), impalas (Aepyceros melampus) and giraffes (Giraffa 


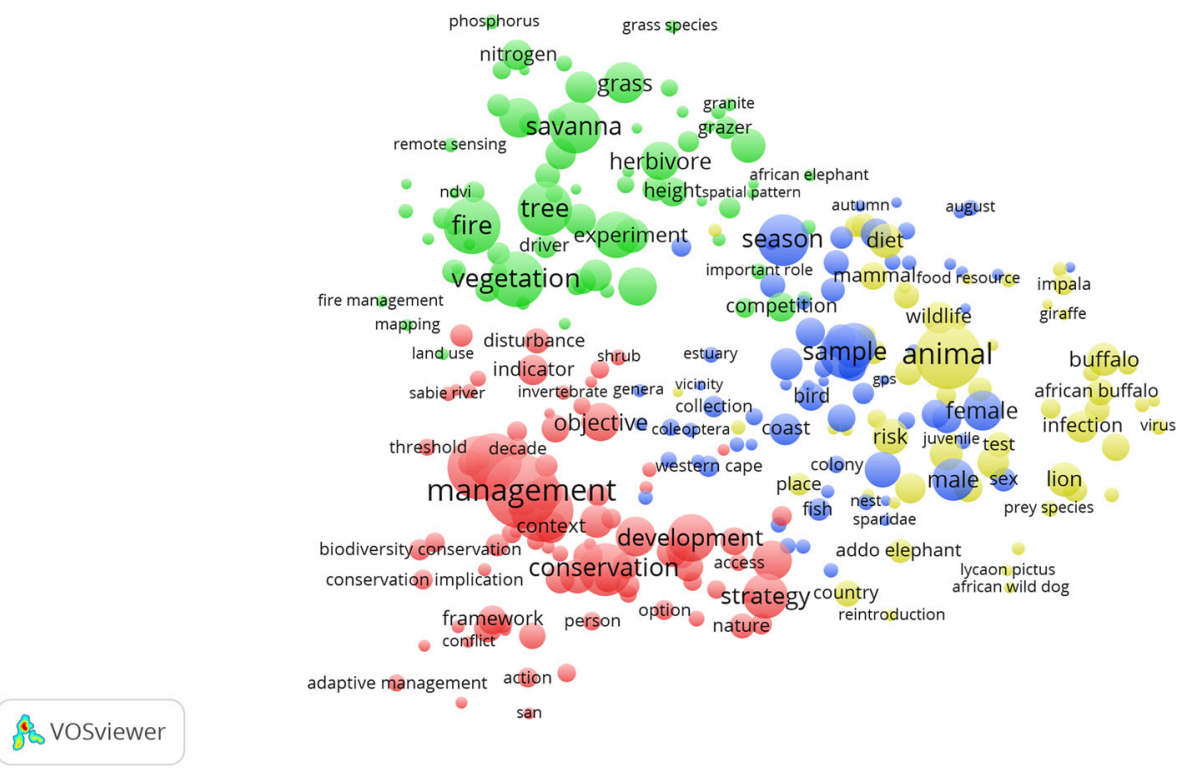

Fig. 7 Visualization of research clusters and topics based on the frequency of words in the titles and abstracts of 853 papers reporting research in all South African National Parks

camelopardalis) (Fig. 8). The mammal-related research was concentrated in three parks (Kruger, Addo Elephant and Kalahari Gemsbok), which accounted for almost all (90\%) of the mammal-related work. Work on insects and terrestrial invertebrates made up $18 \%$ of all animal-related papers, while work on birds accounted for $11 \%$ of all animal-related papers.

Research into ecosystem processes made up the second-largest category after animalrelated research, with $29 \%$ of the papers. These studies formed two distinct clusters (Fig. 9). The first cluster included studies on the links and interactions between fire, vegetation structure and nutrient dynamics, and also examined management implications (left-hand, red). More than a quarter of the papers in this category addressed fire-related research, which was concentrated in the Kruger National Park (60 papers), with the remainder addressing fire in fire-prone parks in fynbos ecosystems (Table Mountain, Garden Route and Bontebok National Parks). The second cluster depicts processes affecting animal population dynamics, including predator-prey relationships, animal diseases, and nutrient cycling and biogeochemistry (right-hand, green). All of the diseaserelated research (41 papers) took place in the Kruger National Park, where the ecology of bovine tuberculosis and foot-and-mouth disease in African buffaloes are the dominant issue.

Almost half of the plant-related research was categorized as descriptive vegetation studies (Fig. 8), and these studies were the only sub-category that was well-distributed across all National Parks (14 out of the 19 parks had vegetation studies carried out in them). Tree-related research made up the next-largest subcategory, and this work was almost exclusively carried out in the Kruger National Park, where there is a concern that growing elephant numbers and frequent fires are driving a steadily-increasing loss of large trees from the landscape (Shannon et al. 2011; Vanak et al. 2012). Research into 

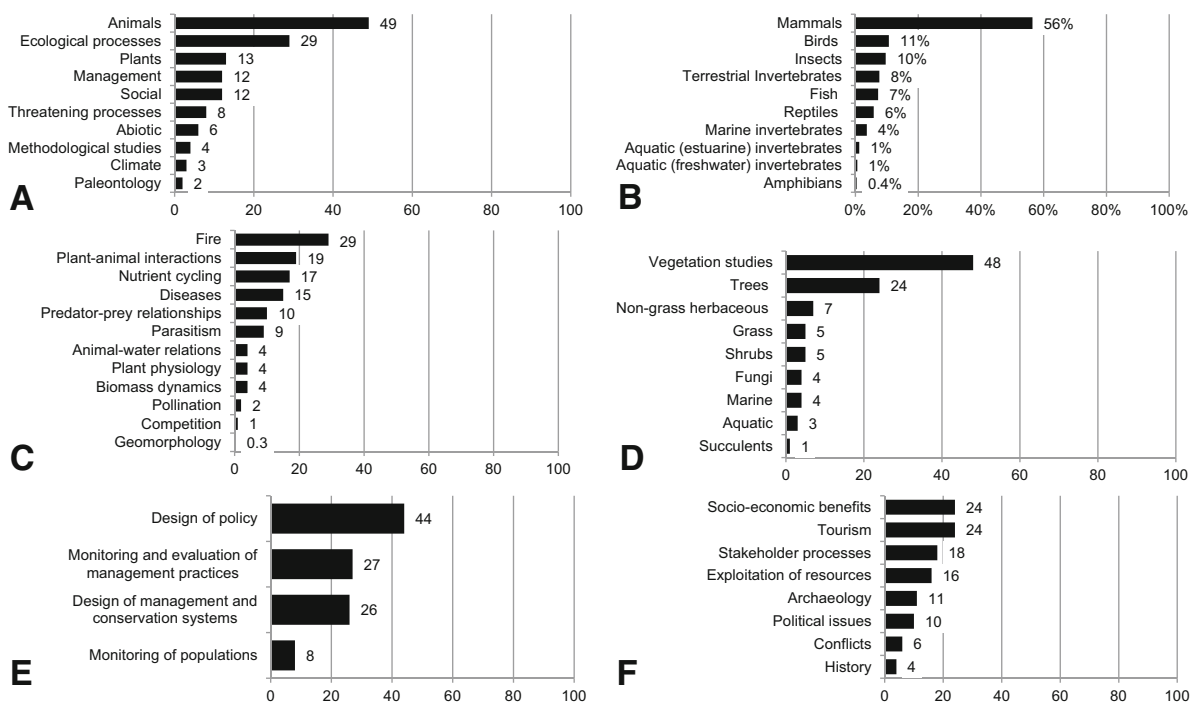

Fig. 8 Percentage of papers that addressed major categories (a) and subcategories (b-f) of research (see Table 2 for full titles of subject categories). The panels are: a major categories of research $(n=1026)$; b subcategories of animal research $(n=498)$; c subcategories of ecological process-related research $(n=300)$; d subcategories of plant research $(n=138)$; e subcategories of management-related research $(n=127)$; and $\mathbf{f}$ subcategories of social research $(n=119)$

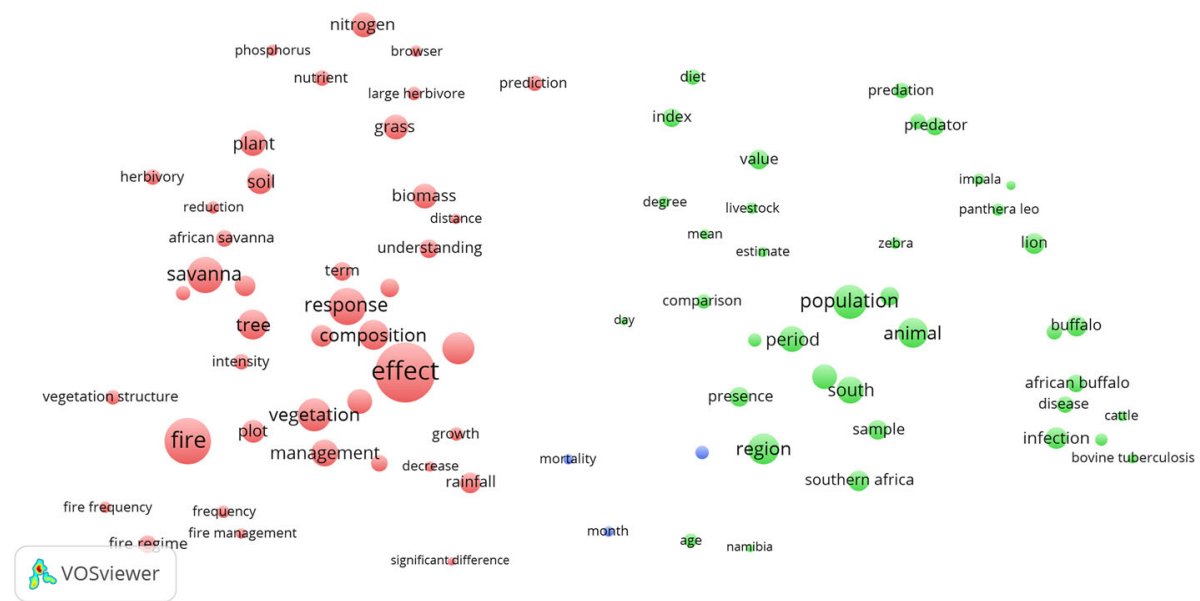

Fig. 9 Visualization of research clusters and topics based on the frequency of words in the titles and abstracts of 268 papers reporting research on ecosystem processes

threatening processes (not depicted in Fig. 8) was largely focused on invasive alien species (62\% of papers in this subcategory).

The above categories of biophysical studies made up the bulk of research, but this was complimented by papers that were categorized as social studies addressing management and socio-economic issues (Fig. 8). Management-related research addressed the 
development of policy as well as implementable practices, and the monitoring and evaluation of management effectiveness. Socio-economic research mainly sought to quantify the benefits of protected areas, and to examine tourism issues such as visitor expectations and perceptions, but they also addressed exploitation of resources, conflicts and political issues.

\section{Focus of embedded researchers versus other authors}

Separation of papers into those that either included or excluded an embedded author or authors revealed noticeable differences in the research focus between these two groups. The research conducted by embedded authors formed three distinct clusters (Fig. 10). These were (1) research into protected area management, including the design of management approaches, their application and consequences (top right, green cluster); (2) factors influencing populations of species, including predator-prey relationships (left-hand, red); and (3) fire effects, especially on the tree-grass balance in savanna ecosystems (the third (bottom right, blue). By contrast, research conducted by external (academic) authors formed four distinct clusters. These were (1) ecosystem processes such as fire and its effects on vegetation, nutrients and biomass (bottom right, blue); (2) issues related to biodiversity in protected areas (top centre, red); (3) research into fish and birds in marine environments (top centre, red); and (4) the ecology of large mammals, including relationships between predators (lions) and prey, and disease effects on buffaloes (lower right, yellow).

\section{Effect of authorship on citation frequency}

Mean citation frequencies for papers in different authorship categories varied threefold, from 15.3 citations for multi-author papers by South African external and embedded authors, to 4.8 for single-author papers by embedded researchers (Table 4). Multi-authored papers including embedded researchers achieved slightly higher citation rates (a mean of 15-15.3 citations per paper) than papers that did not include embedded authors (a mean of 11.7-12.5 citations per paper), suggesting that papers that included embedded authors attracted more attention. This pattern was reversed for single-author papers, where papers by external researchers attracted more citations than papers by embedded researchers (means of 8-11.7, and 4.8 citations per paper respectively, Table 4). The papers that achieved the highest citation rates (Table 5), however, more often excluded embedded authors (12 out of 17 papers), and more often included an international author (13 out of 17 papers).

\section{Journals targeted}

Papers in our dataset were published in 339 journals (a mean of three papers/journal). The most frequently-used journal was Koedoe, the South African National Parks in-house scientific journal ( $8 \%$ of all papers published, Table 6 ). In this regard, papers that listed an embedded researcher as one of the authors appeared in Koedoe more frequently (17\% of all papers with an embedded author) than did papers without embedded authors (5\% of the remaining papers). The 10 most frequently-used journals contained $29 \%$ of all papers in our dataset; of these, four were South African journals and three more were African journals. These journals had lower impact factors than the three international journals in 
A

challenge

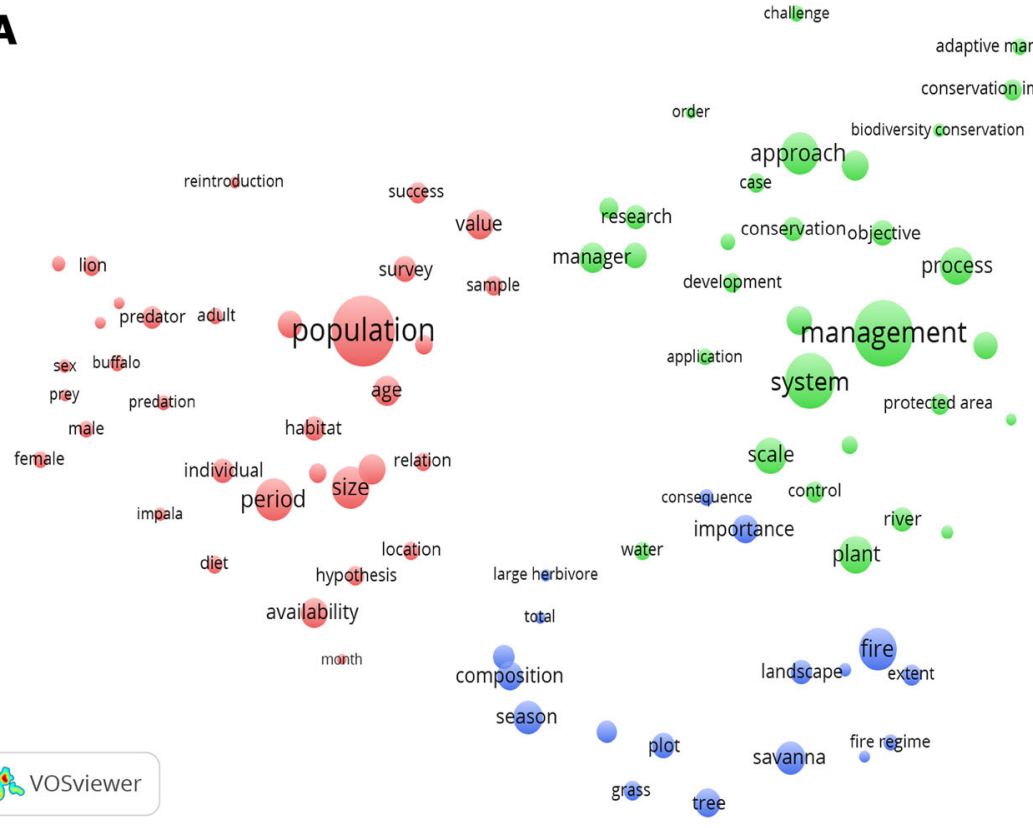

\section{B}

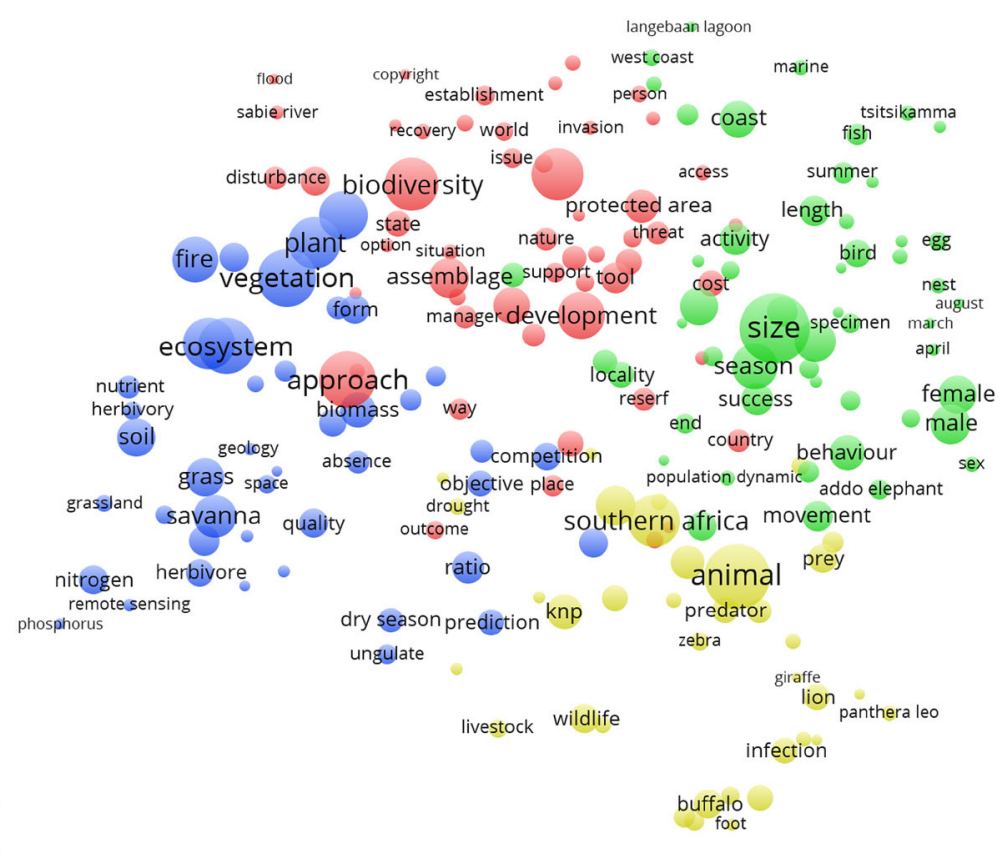

Fig. 10 Comparison of research clusters associated with papers with: a embedded authors $(n=250)$; b papers without any embedded authors $(n=603)$ 
Table 4 Citation statistics of papers in different categories of authorship

\begin{tabular}{|c|c|c|c|c|c|c|}
\hline \multirow[t]{2}{*}{ Authorship of paper } & \multirow[t]{2}{*}{$\begin{array}{l}\text { Number of } \\
\text { papers (all years, } \\
\text { and first } 2 \text { years) }\end{array}$} & \multirow[t]{2}{*}{ Statistic } & \multicolumn{2}{|c|}{$\begin{array}{l}\text { All citations between } \\
\text { date of publication } \\
\text { and } 2013\end{array}$} & \multicolumn{2}{|c|}{$\begin{array}{l}\text { Citations in the first } \\
2 \text { years following the } \\
\text { date of publication }\end{array}$} \\
\hline & & & $\begin{array}{l}\text { Self- } \\
\text { citations } \\
\text { included }\end{array}$ & $\begin{array}{l}\text { Self- } \\
\text { citations } \\
\text { excluded }\end{array}$ & $\begin{array}{l}\text { Self- } \\
\text { citations } \\
\text { included }\end{array}$ & $\begin{array}{l}\text { Self- } \\
\text { citations } \\
\text { excluded }\end{array}$ \\
\hline \multirow{3}{*}{$\begin{array}{l}\text { Multi-authored papers with } \\
\text { international authors, } \\
\text { excluding embedded } \\
\text { authors }\end{array}$} & \multirow{3}{*}{$\begin{array}{l}262 \\
206\end{array}$} & Mean & 11.7 & 9.4 & 5.5 & 3.7 \\
\hline & & Median & 6 & 5 & 3 & 2 \\
\hline & & Range & $0-61$ & $0-47$ & $0-93$ & $0-87$ \\
\hline \multirow{3}{*}{$\begin{array}{l}\text { Multi-authored papers with } \\
\text { South African authors, } \\
\text { excluding embedded } \\
\text { authors }\end{array}$} & \multirow{3}{*}{$\begin{array}{l}84 \\
69\end{array}$} & Mean & 12.5 & 9.5 & 3.8 & 2.4 \\
\hline & & Median & 7 & 4 & 2 & 1 \\
\hline & & Range & $0-102$ & 0-99 & $0-26$ & $0-24$ \\
\hline \multirow{3}{*}{$\begin{array}{l}\text { Multi-authored papers with } \\
\text { international authors, } \\
\text { including embedded } \\
\text { authors }\end{array}$} & \multirow{3}{*}{$\begin{array}{l}104 \\
85\end{array}$} & Mean & 15 & 10.9 & 4.9 & 3 \\
\hline & & Median & 7.5 & 5.5 & 3 & 2 \\
\hline & & Range & $0-114$ & $0-87$ & $0-20$ & $0-14$ \\
\hline \multirow{3}{*}{$\begin{array}{l}\text { Multi-authored papers with } \\
\text { South African authors, } \\
\text { including embedded } \\
\text { authors }\end{array}$} & \multirow{3}{*}{$\begin{array}{l}82 \\
71\end{array}$} & Mean & 15.3 & 11.5 & 4.6 & 2.9 \\
\hline & & Median & 7 & 5 & 3 & 2 \\
\hline & & Range & 0-92 & $0-80$ & $0-19$ & $0-15$ \\
\hline \multirow{3}{*}{$\begin{array}{l}\text { Single-author papers. } \\
\text { International author }\end{array}$} & \multirow{3}{*}{$\begin{array}{l}13 \\
12\end{array}$} & Mean & 8 & 6.5 & 3.2 & 1.4 \\
\hline & & Median & 9 & 4 & 2.5 & 0.5 \\
\hline & & Range & $0-24$ & $0-21$ & $0-8$ & $0-6$ \\
\hline \multirow{3}{*}{$\begin{array}{l}\text { Single-author papers, non- } \\
\text { embedded, South African } \\
\text { authors }\end{array}$} & \multirow{3}{*}{$\begin{array}{l}32 \\
29\end{array}$} & Mean & 11.7 & 9.4 & 3 & 2.1 \\
\hline & & Median & 6 & 5 & 1 & 1 \\
\hline & & Range & $0-61$ & $0-47$ & $0-18$ & $0-16$ \\
\hline \multirow{3}{*}{$\begin{array}{c}\text { Single-author papers, } \\
\text { embedded authors }\end{array}$} & \multirow{3}{*}{$\begin{array}{l}9 \\
9\end{array}$} & Mean & 4.8 & 3.7 & 2.9 & 2 \\
\hline & & Median & 3 & 3 & 1 & 1 \\
\hline & & Range & $0-14$ & $0-11$ & $0-13$ & $0-10$ \\
\hline
\end{tabular}

the top 10 (mean impact factors of 1.07 and 3.17 respectively, Table 6). The most frequently-used journals were all in the biological and environmental subject categories, including biodiversity conservation, biology, ecology, environmental science, marine and freshwater biology, multidisciplinary sciences, plant science, and zoology.

\section{Role of embedded versus external researchers}

Embedded researchers were on average more highly connected than external researchers (mean centrality scores of 17.7 and 6.8 respectively) and more influential (mean betweenness scores of 1047.3 and 70.1 respectively, Table 7). Embedded researchers also featured more prominently among the authors with the highest centrality measures (seven out of the top 10 authors were embedded researchers, for both degree and betweenness metrics). 
Table 5 The ten papers with the highest number of citations [either all citations, or citations within 2 years after publication, the latter denoted by an asterisk $(*)]$

\begin{tabular}{|c|c|c|c|c|c|}
\hline $\begin{array}{l}\text { Topic of } \\
\text { research }\end{array}$ & Reference & $\begin{array}{l}\text { Journal (and } \\
2013 \text { impact } \\
\text { factor) }\end{array}$ & $\begin{array}{l}\text { Category (and } \\
\text { subcategory) }\end{array}$ & Authorship category & $\begin{array}{l}\text { Number } \\
\text { of } \\
\text { citations }\end{array}$ \\
\hline $\begin{array}{l}\text { Determinants of } \\
\text { woody cover } \\
\text { in African } \\
\text { savannas }\end{array}$ & $\begin{array}{l}\text { Sankaran } \\
\text { et al. (2005) }\end{array}$ & Nature (42.351) & $\begin{array}{l}\text { Plants } \\
\text { (vegetation) }\end{array}$ & $\begin{array}{l}\text { Multi-authored with } \\
\text { international and } \\
\text { South African } \\
\text { authors, including } \\
\text { embedded authors }\end{array}$ & $\begin{array}{l}408 \\
37 *\end{array}$ \\
\hline $\begin{array}{l}\text { DNA barcoding } \\
\text { the floras of } \\
\text { biodiversity } \\
\text { hotspots }\end{array}$ & $\begin{array}{l}\text { Lahaye et al. } \\
\text { (2008) }\end{array}$ & $\begin{array}{l}\text { Proceedings of } \\
\text { the National } \\
\text { Academy of } \\
\text { Sciences } \\
(9.809)\end{array}$ & $\begin{array}{l}\text { Plants } \\
\text { (vegetation) }\end{array}$ & $\begin{array}{l}\text { Multi-authored with } \\
\text { international and } \\
\text { South African } \\
\text { authors, excluding } \\
\text { embedded authors }\end{array}$ & $\begin{array}{l}252 \\
93 *\end{array}$ \\
\hline $\begin{array}{l}\text { Effects of fire } \\
\text { and herbivory } \\
\text { on the stability } \\
\text { of savanna } \\
\text { ecosystems }\end{array}$ & $\begin{array}{l}\text { van } \\
\text { Langevelde } \\
\text { et al. (2003) }\end{array}$ & Ecology (5.000) & $\begin{array}{l}\text { Ecosystem } \\
\text { processes } \\
\text { (fire) }\end{array}$ & $\begin{array}{l}\text { Multi-authored with } \\
\text { international and } \\
\text { South African } \\
\text { authors, excluding } \\
\text { embedded authors }\end{array}$ & 222 \\
\hline $\begin{array}{l}\text { Molecular } \\
\text { epidemiology } \\
\text { of foot-and- } \\
\text { mouth disease }\end{array}$ & $\begin{array}{l}\text { Bastos et al. } \\
\text { (2003) }\end{array}$ & $\begin{array}{l}\text { Virus Genes } \\
\quad(1.837)\end{array}$ & $\begin{array}{c}\text { Ecosystem } \\
\text { processes } \\
\text { (disease) }\end{array}$ & $\begin{array}{l}\text { Multi-authored with } \\
\text { international and } \\
\text { South African } \\
\text { authors, including } \\
\text { embedded authors }\end{array}$ & 199 \\
\hline $\begin{array}{l}\text { Individual } \\
\text { aerosol } \\
\text { particles from } \\
\text { biomass } \\
\text { burning }\end{array}$ & $\begin{array}{l}\text { Li et al. } \\
(2003)\end{array}$ & $\begin{array}{l}\text { Journal of } \\
\quad \text { Geophysical } \\
\text { Research } \\
(3.440)\end{array}$ & $\begin{array}{l}\text { Ecosystem } \\
\text { processes } \\
\text { (fire) }\end{array}$ & $\begin{array}{l}\text { Multi-authored with } \\
\text { only international } \\
\text { authors }\end{array}$ & $\begin{array}{l}123 \\
27 *\end{array}$ \\
\hline $\begin{array}{l}\text { Long-term } \\
\text { effects of fire } \\
\text { on woody } \\
\text { vegetation } \\
\text { structure }\end{array}$ & $\begin{array}{l}\text { Higgins et al. } \\
\text { (2007) }\end{array}$ & Ecology (5.000) & $\begin{array}{l}\text { Ecosystem } \\
\text { processes } \\
\text { (fire) }\end{array}$ & $\begin{array}{l}\text { Multi-authored with } \\
\text { international and } \\
\text { South African } \\
\text { authors, including } \\
\text { embedded authors }\end{array}$ & 114 \\
\hline $\begin{array}{l}\text { Predicting } \\
\text { pasture quality } \\
\text { using } \\
\text { continuum- } \\
\text { removed } \\
\text { absorption } \\
\text { features }\end{array}$ & $\begin{array}{l}\text { Mutangaa } \\
\text { et al. (2004) }\end{array}$ & $\begin{array}{l}\text { Remote Sensing } \\
\text { of } \\
\text { Environment } \\
\text { (4.769) }\end{array}$ & $\begin{array}{l}\text { Methodological } \\
\text { studies } \\
\text { (remote } \\
\text { sensing) }\end{array}$ & $\begin{array}{l}\text { Multi-authored with } \\
\text { only international } \\
\text { authors }\end{array}$ & 112 \\
\hline $\begin{array}{c}\text { Prey preferences } \\
\text { of the leopard }\end{array}$ & $\begin{array}{l}\text { Hayward } \\
\text { et al. (2006) }\end{array}$ & $\begin{array}{l}\text { Journal of } \\
\text { Zoology } \\
(1.947)\end{array}$ & $\begin{array}{l}\text { Ecosystem } \\
\text { processes } \\
\text { (predator- } \\
\text { prey } \\
\text { relationships) }\end{array}$ & $\begin{array}{l}\text { Multi-authored with } \\
\text { South African } \\
\text { authors, including } \\
\text { embedded authors }\end{array}$ & 104 \\
\hline $\begin{array}{l}\text { Large predator } \\
\text { size and the } \\
\text { range of prey } \\
\text { species sizes }\end{array}$ & $\begin{array}{l}\text { Radloff and } \\
\text { Du Toit } \\
(2004)\end{array}$ & $\begin{array}{l}\text { Journal of } \\
\text { Animal } \\
\text { Ecology } \\
(4.726)\end{array}$ & $\begin{array}{l}\text { Ecosystem } \\
\text { processes } \\
\text { (predator- } \\
\text { prey } \\
\text { relationships) }\end{array}$ & $\begin{array}{l}\text { Multi-authored with } \\
\text { South African } \\
\text { authors, excluding } \\
\text { embedded authors }\end{array}$ & 102 \\
\hline
\end{tabular}


Table 5 continued

\begin{tabular}{|c|c|c|c|c|c|}
\hline $\begin{array}{l}\text { Topic of } \\
\text { research }\end{array}$ & Reference & $\begin{array}{l}\text { Journal (and } \\
2013 \text { impact } \\
\text { factor) }\end{array}$ & $\begin{array}{l}\text { Category (and } \\
\text { subcategory) }\end{array}$ & Authorship category & $\begin{array}{l}\text { Number } \\
\text { of } \\
\text { citations }\end{array}$ \\
\hline $\begin{array}{l}\text { Offshore intra- } \\
\text { specific } \\
\text { competition } \\
\text { between } \\
\text { seabirds }\end{array}$ & $\begin{array}{l}\text { Grémillet } \\
\text { et al. (2004) }\end{array}$ & $\begin{array}{l}\text { Marine Ecology } \\
\text { Progress } \\
\text { Series }(2.640)\end{array}$ & $\begin{array}{l}\text { Animals (birds) } \\
\text { Ecosystem } \\
\text { processes } \\
\text { (competition) }\end{array}$ & $\begin{array}{l}\text { Multi-authored with } \\
\text { international and } \\
\text { South African } \\
\text { authors, excluding } \\
\text { embedded authors }\end{array}$ & $\begin{array}{l}99 \\
22 *\end{array}$ \\
\hline $\begin{array}{l}\text { Predator-prey } \\
\text { size } \\
\text { relationships in } \\
\text { a large- } \\
\text { mammal food } \\
\text { web }\end{array}$ & $\begin{array}{l}\text { Owen-Smith } \\
\text { and Mills } \\
(2008)\end{array}$ & $\begin{array}{l}\text { Journal of } \\
\text { Animal } \\
\text { Ecology } \\
(4.726)\end{array}$ & $\begin{array}{l}\text { Ecosystem } \\
\text { processes } \\
\text { (predator- } \\
\text { prey } \\
\text { relationships) }\end{array}$ & $\begin{array}{l}\text { Multi-authored with } \\
\text { South African } \\
\text { authors, including } \\
\text { embedded authors }\end{array}$ & $26^{*}$ \\
\hline $\begin{array}{l}\text { Causes of locally } \\
\text { high elephant } \\
\text { numbers }\end{array}$ & $\begin{array}{l}\text { van Aarde } \\
\text { and Jackson } \\
(2007)\end{array}$ & $\begin{array}{l}\text { Biological } \\
\text { Conservation } \\
(4.036)\end{array}$ & $\begin{array}{l}\text { Animals } \\
\text { (mammals) }\end{array}$ & $\begin{array}{l}\text { Multi-authored with } \\
\text { only South African } \\
\text { authors }\end{array}$ & $25^{*}$ \\
\hline $\begin{array}{l}\text { Molecular } \\
\text { epidemiology } \\
\text { of foot-and- } \\
\text { mouth disease } \\
\text { virus }\end{array}$ & $\begin{array}{l}\text { Knowles and } \\
\text { Samuel } \\
(2003)\end{array}$ & $\begin{array}{l}\text { Virus Research } \\
\quad(2.827)\end{array}$ & $\begin{array}{c}\text { Ecosystem } \\
\text { processes } \\
\text { (disease) }\end{array}$ & $\begin{array}{l}\text { Multi-authored with } \\
\text { only international } \\
\text { authors }\end{array}$ & $24 *$ \\
\hline $\begin{array}{l}\text { Vulnerability of } \\
\text { African } \\
\text { mammals to } \\
\text { anthropogenic } \\
\text { climate change }\end{array}$ & $\begin{array}{l}\text { Thuiller et al. } \\
\text { (2006) }\end{array}$ & $\begin{array}{l}\text { Global Change } \\
\text { Biology } \\
(8.224)\end{array}$ & $\begin{array}{l}\text { Threatening } \\
\text { processes } \\
\text { (climate } \\
\text { change) }\end{array}$ & $\begin{array}{l}\text { Multi-authored with } \\
\text { international and } \\
\text { South African } \\
\text { authors, excluding } \\
\text { embedded authors }\end{array}$ & $24 *$ \\
\hline $\begin{array}{l}\text { Impacts of } \\
\text { herbivores on } \\
\text { the structural } \\
\text { diversity of } \\
\text { savannas. }\end{array}$ & $\begin{array}{l}\text { Asner et al. } \\
\text { (2009) }\end{array}$ & $\begin{array}{l}\text { Proceedings of } \\
\text { the National } \\
\text { Academy of } \\
\text { Sciences } \\
(9.809)\end{array}$ & $\begin{array}{l}\text { Ecosystem } \\
\text { processes } \\
\text { (Plant-animal } \\
\text { interactions } \\
\text { and herbivory) }\end{array}$ & $\begin{array}{l}\text { Multi-authored with } \\
\text { only international } \\
\text { authors }\end{array}$ & $23 *$ \\
\hline $\begin{array}{l}\text { Remote sensing } \\
\text { of fire severity }\end{array}$ & $\begin{array}{l}\text { Roy et al. } \\
\text { (2006) }\end{array}$ & $\begin{array}{l}\text { Geoscience and } \\
\text { Remote } \\
\text { Sensing } \\
\text { Letters } \\
(1.809)\end{array}$ & $\begin{array}{l}\text { Methodological } \\
\text { studies } \\
\text { (remote } \\
\text { sensing) }\end{array}$ & $\begin{array}{l}\text { Multi-authored with } \\
\text { only international } \\
\text { authors }\end{array}$ & $22 *$ \\
\hline $\begin{array}{l}\text { Impacts of } \\
\text { climate change } \\
\text { on vegetation }\end{array}$ & $\begin{array}{l}\text { Scheiter and } \\
\text { Higgins } \\
(2009)\end{array}$ & $\begin{array}{l}\text { Global Change } \\
\text { Biology } \\
(8.224)\end{array}$ & $\begin{array}{l}\text { Threatening } \\
\text { processes } \\
\text { (climate } \\
\text { change) }\end{array}$ & $\begin{array}{l}\text { Multi-authored with } \\
\text { only international } \\
\text { authors }\end{array}$ & $22 *$ \\
\hline
\end{tabular}

\section{Discussion}

\section{Protected areas as research laboratories}

We were interested in examining the degree to which National Parks acted as outdoor laboratories that would attract researchers and generate knowledge about relatively undisturbed ecosystems. The Kruger National Park, where most of the work was done, has clearly played this role. This park in particular provides an increasingly rare, relatively intact ecosystem with a full complement of extant mega-fauna on which to base research, 
Table 6 The ten journals most frequently targeted by authors of papers addressing South African National Parks between 2003 and 2013

\begin{tabular}{|c|c|c|c|}
\hline Journal & $\begin{array}{l}\text { Number of papers (\% of } \\
\text { all papers) }\end{array}$ & Subject categories & $\begin{array}{l}\text { Journal impact } \\
\text { factor (2013) }\end{array}$ \\
\hline Koedoe & $83(8)$ & $\begin{array}{l}\text { Biodiversity } \\
\text { Conservation } \\
\text { Biology }\end{array}$ & 1.486 \\
\hline $\begin{array}{l}\text { South African Journal of } \\
\text { Botany }\end{array}$ & $33(3)$ & Plant Sciences & 1.340 \\
\hline Biological Conservation & $30(3)$ & $\begin{array}{l}\text { Biodiversity } \\
\text { Conservation } \\
\text { Ecology } \\
\text { Environmental } \\
\text { Sciences }\end{array}$ & 4.036 \\
\hline African Journal of Ecology & $26(3)$ & Ecology & 1.000 \\
\hline $\begin{array}{l}\text { South African Journal of } \\
\text { Wildlife Research }\end{array}$ & $25(2)$ & $\begin{array}{l}\text { Ecology } \\
\text { Zoology }\end{array}$ & 0.711 \\
\hline $\begin{array}{l}\text { African Journal of Marine } \\
\text { Science }\end{array}$ & $25(2)$ & $\begin{array}{l}\text { Marine and Freshwater } \\
\text { Biology }\end{array}$ & 1.057 \\
\hline Plos One & $23(2)$ & $\begin{array}{l}\text { Multidisciplinary } \\
\text { Sciences }\end{array}$ & 3.534 \\
\hline African Zoology & $23(2)$ & Zoology & 0.848 \\
\hline Journal of Zoology & $20(2)$ & Zoology & 1.947 \\
\hline $\begin{array}{l}\text { South African Journal of } \\
\text { Science }\end{array}$ & $17(2)$ & $\begin{array}{l}\text { Multidisciplinary } \\
\text { Sciences }\end{array}$ & 1.031 \\
\hline
\end{tabular}

and it also borders many different land-uses, allowing comparative and socio-ecological studies. There are however other factors that characterize those parks that are more likely to act as outdoor laboratories than others. A comparison of the five parks in which the most research was carried out (the "utilised parks", Kruger, Garden Route, Table Mountain, Addo Elephant and Kalahari Gemsbok, Fig. 4) with the five in which the least research was carried out (the "under-utilized parks", Golden Gate, Namaqua, Tankwa Karoo, Camdeboo and Mokala) suggests that several interacting factors may contribute to a park's attractiveness as a research destination. These factors are discussed below.

\section{Availability of research facilities}

Three of the utilised parks (Kruger, Kalahari Gemsbok and Addo Elephant) have dedicated subsidized accommodation facilities for researchers, while none of the under-utilized parks have such facilities. These research facilities were created because of the research interest in these parks, but probably at the same time stimulate and attract further research interest.

\section{Existence of experiments and data sets}

The utilized parks, and in particular the Kruger National Park, all have long-term data sets or experiments that can support research. In Kruger this includes a long-term experiment investigating the effects of fire (Biggs et al. 2003; van Wilgen et al. 2007), and both management and experimental herbivore exclosures where the long-term effects of herbivory can be examined (see, for example, Asner et al. 2009; Scogings 2011). In addition, 
Table 7 A comparison of embedded and external authors ranked according to two centrality measures. Means and medians for all authors $(n=2003)$ given at the end of the table. Embedded researchers are indicated by an asterisk (*)

\begin{tabular}{|c|c|c|c|c|}
\hline \multirow{2}{*}{$\frac{\text { Rank }}{1}$} & \multicolumn{2}{|l|}{ Degree centrality } & \multicolumn{2}{|c|}{ Betweenness centrality } \\
\hline & C. C. Grant* & 105 & S. M. Ferreira* & 19,332 \\
\hline 2 & N. Govender* & 100 & C. C. Grant* & 9017 \\
\hline 3 & R. G. Bengis* & 85 & R. Slotow & 8867 \\
\hline 4 & M. G. L. Mills* & 84 & C. Packer & 7422 \\
\hline 5 & R. Slotow & 83 & I. P. J. Smit* & 6577 \\
\hline 6 & M. Hofmeyr* & 74 & M. Hofmeyr* & 6186 \\
\hline 7 & S. M. Ferreira* & 70 & N. Owen-Smith & 6075 \\
\hline 8 & P. E. Buss* & 64 & D. Zimmermann* & 5346 \\
\hline 9 & H. H. T. Prins & 63 & A. R. Deacon* & 5178 \\
\hline 10 & W. J. Bond & 62 & D. Govender* & 4792 \\
\hline 11 & H. C. Biggs* & 56 & M. C. Oosthuizen & 3967 \\
\hline 12 & R. M. Randall* & 51 & I. J. Whyte* & 3847 \\
\hline 13 & G. I. H. Kerley & 50 & J. M. Botha* & 3729 \\
\hline 14 & M. J. S. Peel & 50 & P. E. Buss* & 3679 \\
\hline 15 & F. van Langevelde & 49 & P. C. Cross & 3455 \\
\hline 16 & I. P. J. Smit* & 49 & H. C. Biggs* & 3356 \\
\hline 17 & D. F. Keet* & 48 & M. A. McGeoch* & 3347 \\
\hline 18 & M. A. McGeoch* & 47 & S. J. O’Brien & 3316 \\
\hline 19 & A. K. Skidmore & 46 & M. J. S. Peel & 3297 \\
\hline \multirow[t]{5}{*}{20} & M. H. Knight* & 44 & D. F. Keet* & 3031 \\
\hline & $\begin{array}{l}\text { Mean (and range) for all embedded } \\
\text { authors }\end{array}$ & $17.7(1-105)$ & & $1047.3(0-19,332)$ \\
\hline & $\begin{array}{l}\text { Mean (and range) for all external } \\
\text { authors }\end{array}$ & $6.8(1-83)$ & & $70.1(0-8867)$ \\
\hline & Median for all embedded authors & 8 & & 54 \\
\hline & Median for all external authors & 5 & & 0 \\
\hline
\end{tabular}

many long-term data sets exist and have been used to attract support many research initiatives (Freitag 1998). Embedded researchers in Kruger have also set up four research "supersites", which provide a geographic focus for future research effort (Smit et al. 2013). It is intended that these supersites will focus long-term data collection, data sharing and co-learning, and ultimately lead to a more integrated, multi-scaled and multi-temporal understanding of savannas. Garden Route and Table Mountain both have a long history of vegetation-related research that precedes their proclamation as National Parks (see, for example, Thuiller et al. 2007; Seydack et al. 2011; van Daalen 1991). Addo Elephant National Park also has exclosure plots where the effects of herbivory have been studied (Lombard et al. 2001) and vegetation plots that have been monitored for over 40 years (Penzhorn et al. 1974; Landman et al. 2014). The under-utilized parks do not host any experiments, nor do they have any long-term data sets. 


\section{Proximity to collaborating universities}

With the exception of Kalahari Gemsbok $(>900 \mathrm{~km})$ and Kruger $(400 \mathrm{~km})$, the utilized parks are very close $(<50 \mathrm{~km})$ to one or more of the collaborating universities. A large proportion of papers addressing issues in parks other than Kruger were produced by the Cape Town, Stellenbosch and Nelson Mandela Metropolitan Universities (Fig. 3). These universities are located in the Western and Eastern Cape Provinces, and are close to the Table Mountain, Garden Route and Addo Elephant National Parks, where fynbos and thicket vegetation, and marine environments occur. Although a large proportion of papers produced by these Cape universities addressed savanna ecosystems (45, 41, and $18 \%$ of papers for Cape Town, Stellenbosch and Nelson Mandela Metropolitan respectively), they also addressed fynbos and marine ecosystem types (42, 40, and $29 \%$ of papers for Cape Town, Stellenbosch and Nelson Mandela Metropolitan respectively). In addition, $36 \%$ of the papers produced by Nelson Mandela Metropolitan University addressed the thicket ecosystem type, which is dominant in the nearby Addo Elephant National Park. Both Kruger and Kalahari Gemsbok compensate for the disadvantage of distance from collaborating universities by providing dedicated accommodation for researchers. The under-utilized parks, on the other hand, are all remote $(300-700 \mathrm{~km})$ from any of the prominent collaborating universities, and lack accommodation for researchers.

\section{Economic viability}

All of the utilised parks had higher ratios of income to expenditure compared to the underutilized parks (SANParks unpublished data). Parks with higher economic viability are those that attract larger numbers of visitors, and are therefore arguably more attractive for a range of reasons.

\section{Park age}

Utilized parks are generally those that were established relatively long ago. Three of the utilized parks were established in the early twentieth century (Table 1). The Garden Route National Park, although established in its current expanded form in 2009, has existed as the Tsitsikamma National Park since the early 1960s. The exception is the Table Mountain National Park, established as a National Park in 1998, but with some previous conservation history (van Wilgen 1996). By comparison, under-utilized parks tend to be more recentlyestablished, three of them as recently as 2005-2007 (Table 1).

\section{Park size}

The utilized parks also include the four largest of the South African National Parks (ranging in size from 164,233 to 1962,362 ha), with the exception again being the Table Mountain National Park (Table 1). Three of the under-utilized parks are relatively small $(<20,000$ ha), but both the Namaqua and Tankwa Karoo parks are relatively large $(>120,000$ ha $)$.

It appears from the above that researchers have favoured older, larger, and arguably more aesthetically-appealing parks that are either close to hand or that have subsidized research accommodation facilities, and that have established experimental setups or useful 
long-term data. Research activities in some of the newer and smaller parks may still grow, but they will remain at a disadvantage as they are relatively remote and they lack facilities to support collaborating researchers.

\section{Relevance of research to management of protected areas}

We wanted to know whether research has been useful in producing a body of knowledge that would inform the development of management policies and practices in South Africa's National Parks. The Kruger National Park in particular has benefited for several decades from a strong background and culture of collaboration between managers and researchers (Biggs and Rogers 2003; Joubert 2007), leading eventually to a robust system of adaptive management in the early 1990s (Roux and Foxcroft 2011; van Wilgen and Biggs 2011). However, the usefulness of research has not always come about in the way that was originally envisaged. For example, the Kruger National Park Rivers Research Programme (Breen 2000) that was initiated in 1988, initially intended to focus on the biophysical aspects of river ecology. However, it was later recognized that effective river conservation would depend more on active engagement with managers and other stakeholders, and much less on ecological understanding, leading to a substantial change in the focus of the research project (Pollard et al. 2011). Another example is provided by the Kruger National Park's long-term fire experiment, which was originally intended to provide direct input into fire management policy, but was less influential in doing this than would have been expected. In the first place, the variety of fire treatments had less effect on the vegetation than was originally expected. The design of the experiment also reflected the ecological understanding of the 1950s (stability and regularity), and did not cater for changing ecological paradigms (flux and variability); as a result, the experiment had little direct influence on changes in management policy (van Wilgen et al. 2007). Notwithstanding this, fire managers did accept that basic research influences the understanding of fundamental ecosystem function, and they recognized that the fire experiment did contribute to predictive understanding (van Wilgen et al. 2007). The Kruger National Park also found itself unable, in the early 1990s, to defend its policy of elephant culling, due largely to a lack of scientific evidence for putative damage by large numbers of elephants. Elephant culling was terminated pending the outcome of an assessment of the issue (Scholes and Mennel 2008), while subsequent research has begun to build a much clearer picture of the effects of elephants and fires on tree populations (Shannon et al. 2011; Vanak et al. 2012; Asner and Levick 2012). The information generated by these exercises will almost certainly place managers in a better position to defend any policy that they come up with to manage elephants in future.

Disease-related research was also confined to the Kruger National Park, where bovine tuberculosis was transferred in the 1960s from domestic cattle to wild buffalo populations, and later to lions. There was a concern that this introduced disease would negatively affect wild populations, and hence research has sought to develop an understanding of effects and to monitor factors related to disease prevalence. To date, no drastic management interventions have been necessary. In other National Parks in South Africa, either the wild buffaloes have remained free of disease, or the parks have been re-stocked with diseasefree animals.

In contrast to Kruger (proclaimed as a National Park in 1926), the five National Parks in the fynbos ecosystems are relatively new. With the exception of the (relatively small) Bontebok National Park (proclaimed 1961), and the West Coast National Park (proclaimed 1985), the other parks have all been established relatively recently (6-17 years ago, 
Table 1), and the Cape Research Centre was only established in 2008. The area has therefore until very recently lacked the research infrastructure that characterises Kruger, and management guidelines for these ecosystems have been based on research undertaken in other areas (see, for example, van Wilgen 2009). The remaining National Parks have not had much attention from researchers yet (only $25 \%$ of papers addressed issues in 15 out of 19 parks, Fig. 4). The possible reasons for this are discussed above.

The bulk of research carried out has also arguably not always addressed the priority threats to conservation. For example, attendees of the Kruger National Park's 2013 annual research meeting participated in an exercise to identify and prioritize threats to the conservation of protected savanna ecosystems. The findings were based on inputs from 133 participants, including researchers, managers and post-graduate students (I.P.J. Smit, unpublished data). A total of 33 threats were identified. Of the top 10 priority threats, four were of a biophysical nature, and included the degradation of freshwater ecosystems outside of protected areas, global change, changing land-use outside of protected areas, and invasive alien species. The remaining six were of a social nature, and included issues related to poor governance, relationships with neighbouring communities, changing social environments and norms, political pressures, and poaching. A comparison of these priorities with the published papers suggests that the social issues, regarded as very important, have received relatively little attention from researchers. Social research made up less than $12 \%$ of all papers, and half of these were on socio-economic benefits, tourism, and visitor perceptions (panel F in Fig. 8). Research into freshwater ecosystems contributed $5 \%$ of all papers, while climate, and climate change-related papers (Climate, climate change; and Threatening processes, climate change in Table 2) contributed $0.8 \%$ of all papers. Invasive alien species received somewhat more attention, contributing $5.3 \%$ of all papers.

While the above may be interpreted as indicating that research has neglected some priority issues, it also needs to be considered that many of these issues will not be solved primarily by research. This became apparent with regard to the social threats in the Kruger National Park Rivers Research Programme (Breen 2000), as mentioned above. Those tasked with addressing these issues prefer processes of engagement with stakeholders, and tend to pay much less attention to the publication of their findings. On the biophysical side, however, there is certainly scope for increasing the research effort regarding the management and conservation of freshwater ecosystems in a holistic way. Global change issues and how they will affect protected areas, will also require research attention, and this has already been initiated (see, for example van Wilgen et al. 2013, 2015; van Wilgen and McGeoch 2014).

It is also evident that research into marine ecosystems has not featured strongly, despite the fact that five National Parks include substantial marine components (Table 1). National Parks that include marine components are relatively recent additions (or, in the case of the Addo Elephant National Park, the marine component is a recent addition). Marine research contributed $8 \%$ of all papers, and half of these papers were from the Garden Route National Park, which includes the former Tsitsikamma National Park with a substantial marine component that was established in the 1960s. Research there has been instrumental in demonstrating that populations of resident reef fish can recover remarkably when inshore marine areas are protected (Buxton and Smale 1989; Cowley et al. 2010), and this has provided motivation for the establishment of additional marine protected areas elsewhere. 


\section{The benefits of embedded researchers}

Our analysis suggests that embedded researchers play an important role in the generation of knowledge relevant to the management of protected areas. They are important collaborators in a wider network of researchers with interests in ecosystem conservation and management. They provide their external colleagues with access to data and they offer the opportunity to address real-world conservation challenges in protected areas. Within the community that conducts research in protected areas, embedded researchers are well-

Fig. 11 a Hypothetical flow of information in a protected area research network with an embedded research capacity. b The same system without an embedded research capacity

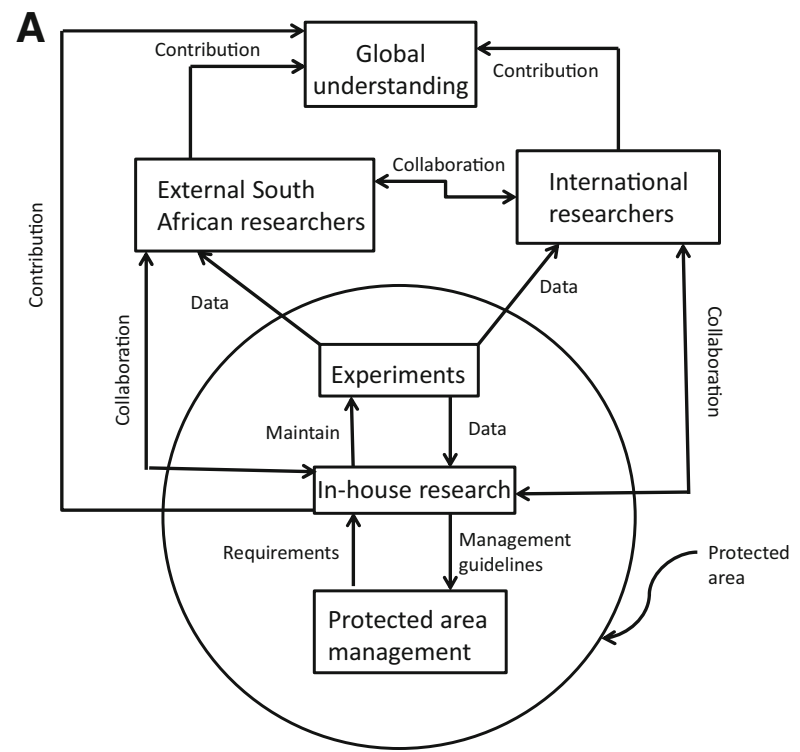

B

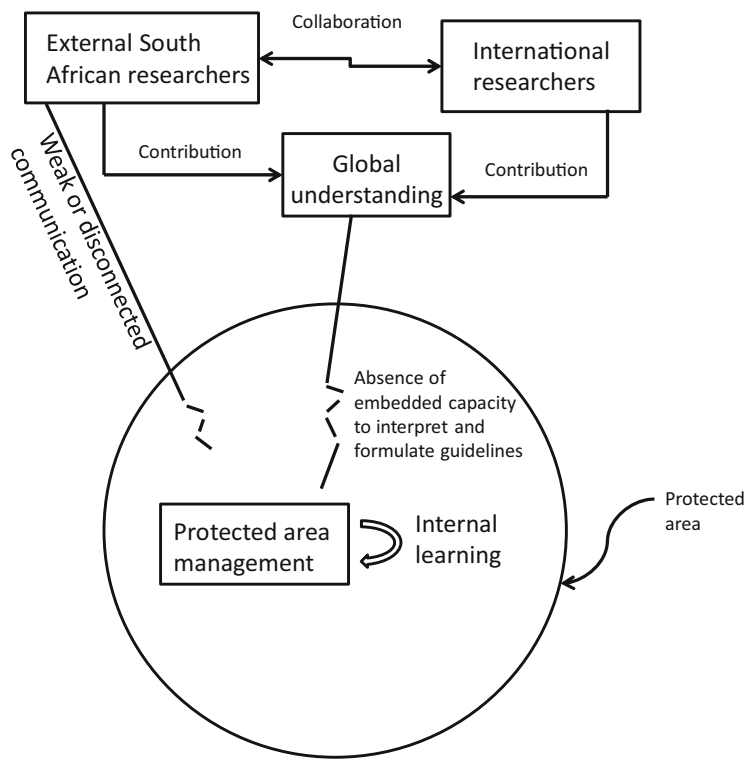


connected and influential. Collaborative research involving author teams made up of embedded and external researchers are more likely to focus on management-relevant issues than teams of external researchers alone (Fig. 10), get slightly more citations on average (Table 4), involve more co-authors (5 co-authors compared to 3.3) and hence are more collaborative. The protected area management system benefits through the generation of a large amount of additional relevant research that would arguably have been much less in the absence of embedded collaborators. Of the 1026 papers in our dataset, 267 were collaborative efforts between embedded and external researchers, and a further 718 papers were generated without authorship from embedded researchers, although embedded researchers often provided inputs and logistical support to these projects as well. This additional output has been generated in no small degree by the availability of historical data collected by, and from experiments set up and maintained by embedded researchers. It also arises from intellectual engagement between embedded and external researchers, and is due in part to the existence of a culture that encourages research in protected areas.

The maintenance of an in-house research capacity can therefore be instrumental in improving protected area management by understanding management requirements, maintaining appropriate experiments, and leveraging the development of relevant knowledge and management guidelines. The ability to leverage further benefits through collaboration with national and international external research partners is due to an organizational culture that embraces research (Fig. 11a). External researchers also benefit through access to research sites, data, and the challenge of real-world management requirements, and are able to also make contributions to global understanding as well as to shaping local solutions. In the absence of an in-house research capacity, communication between researchers and managers is weak, and managers are disadvantaged by the absence of a capacity to interpret new understanding as it emerges; consequently, they have to rely on internal learning to adapt management practices (Fig. 11b). We believe that the maintenance of an in-house research capacity will benefit protected area management compared to a situation without such a capacity, which would be characterized by weak or disconnected communication between the research and management communities.

Acknowledgments This research was supported by the DST-NRF Centre of Excellence for Invasion and the National Research Foundation (Grant 87550 to BWvW). We thank Llewellyn Foxcroft and Innes Ferreira for assistance in locating publications, and Andy Liu for assistance with the calculation of centrality measures.

\section{References}

Adams, W. A., \& Sandbrook, C. (2013). Conservation, evidence and policy. Oryx, 47, 329-335.

Asner, G. P., \& Levick, S. R. (2012). Landscape-scale effects of herbivores on treefall in African savannas. Ecology Letters, 15, 1211-1217.

Asner, G. P., Levick, S. R., Kennedy-Bowdoin, T., Knapp, D. E., Emerson, R., Jacobson, J., et al. (2009). Large-scale impacts of herbivores on the structural diversity of African savannas. Proceedings of the National Academy of Science U. S. A., 106, 4947-4952.

Bastos, A. D. S., Anderson, E. C., Bengis, R. G., Keet, D. F., Winterbach, H. K., \& Thomson, G. R. (2003). Molecular epidemiology of SAT3-type foot-and-mouth disease. Virus Genes, 27, 283-290.

Biggs, R., Biggs, H. C., Dunne, T. T., Govender, N., \& Potgieter, A. L. F. (2003). Experimental burn plot trial in the Kruger National Park: History, experimental design and suggestions for data analysis. Koedoe, 46, 1-15.

Biggs, H. C., \& Rogers, K. H. (2003). An adaptive system to link science, monitoring and management in practice. In J. T. Du Toit, K. H. Rogers, \& H. C. Biggs (Eds.), The Kruger experience: Ecology and management of savanna heterogeneity (pp. 59-80). Washington, DC: Island Press. 
Breen, C. M. (2000). The KNP Rivers research programme final report. Report TT130/ 00. Pretoria: Water Research Commission.

Buxton, C. D., \& Smale, C. D. (1989). Abundance and distribution patterns of three temperate marine fish (Teleostei: Sparidae) in exploited and unexploited areas off the southern Cape coast. Journal of Applied Ecology, 26, 441-451.

Cowley, P. D., Brouwer, S. L., \& Tilney, R. L. (2010). The role of the Tsitsikamma National Park in the management of four shore-angling fish along the south-eastern Cape coast of South Africa. South African Journal of Marine Science, 24, 27-35.

Freitag, S. (1998). The Kruger National Park and the analysis of historic datasets: Where are we going? South African Journal of Science, 94, 146.

Grémillet, D., Dell'Omo, G., Ryan, P. G., Peters, G., Ropert-Coudert, Y., \& Weeks, S. J. (2004). Offshore diplomacy or how seabirds mitigate intra-specific competition: A case study based on GPS tracking of Cape gannets from neighbouring colonies. Marine Ecology Progress Series, 268, 265-279.

Hayward, M. W., Henschel, P., O’Brien, J., Hofmeyr, M., Balme, G., \& Kerley, G. I. H. (2006). Prey preferences of the leopard (Panthera pardus). Journal of Zoology, 270, 298-393.

Higgins, S. I., Bond, W. J., February, E. C., Bronn, A., Euston-Brown, D. I., Enslin, B., et al. (2007). Effects of four decades of fire manipulation on woody vegetation structure in savanna. Ecology, 88, 1119-1125.

Hoffmann, M., Hilton-Taylor, C., Angulo, A., Böhm, M., Brooks, T. M., Butchart, S. H. M., et al. (2010). The impact of conservation on the status of the world's vertebrates. Science, 330, 1503-1509.

Jenkins, L. D., Maxwell, S. M., \& Fisher, E. (2012). Increasing conservation impact and policy relevance of research through embedded experiences. Conservation Biology, 26, 740-742.

Joubert, S. (2007). The Kruger National Park: A history. Johannesburg: High Branching.

Knowles, N. J., \& Samuel, A. R. (2003). Molecular epidemiology of foot-and-mouth disease virus. Virus Research, 91, 65-80.

Lahaye, R., van der Bank, M., Bogarin, M. D., Warner, J., Pupulin, F., Gigot, G., et al. (2008). DNA barcoding the floras of biodiversity hotspots. PNAS, 105, 2923-2928.

Landman, M., Schoeman, D. S., Hall-Martin, A. J., \& Kerley, G. I. H. (2014). Long-term monitoring reveals differing impacts of elephant on elements of a canopy shrub community. Ecological Applications, 24, 2002-2012.

Leader-Williams, N., \& Dublin, H. T. (2000). Charismatic megafauna as flagship species. In A. Entwistle \& N. Dunstone (Eds.), Priorities for the conservation of mammalian diversity: Has the Panda had its day? (pp. 53-81). Cambridge: Cambridge University Press.

Li, J., Posfai, M., Hobbs, P. V., \& Buseck, P. R. (2003). Individual aerosol particles from biomass burning in southern Africa: 2. Compositions and aging of inorganic particles. Journal of Geophysical Research, 108(D13), 8484.

Lombard, A. T., Johnson, C. F., Cowling, R. M., \& Pressey, R. L. (2001). Protecting plants from elephants: Botanical reserve scenarios within the Addo Elephant National Park, South Africa. Biological Conservation, 102, 191-203.

Lui, X., Bollen, J., Nelson, M. L., \& van de Sompel, H. (2005). Co-authorship networks in the digital research community. Information Processing and Management, 41, 1462-1480.

Mutangaa, O., Skidmor, A. K., \& Prins, H. H. T. (2004). Predicting in situ pasture quality in the Kruger National Park, South Africa, using continuum-removed absorption features. Remote Sensing of Environment, 89, 393-408.

Owen-Smith, N., \& Mills, M. G. L. (2008). Predator-prey size relationships in an African large-mammal food web. Journal of Animal Ecology, 77, 173-183.

Penzhorn, B. L., Robbertse, P. J., \& Olivier, M. C. (1974). The influence of the African elephant on the vegetation of the Addo Elephant National Park. Koedoe, 17, 137-158.

Pollard, S., Du Toit, D., \& Biggs, H., (2011). River management under transformation: The emergence of strategic adaptive management of river systems in the Kruger National Park. Koedoe, 53(2), Art. \#1011, 14 pages. doi:10.4102/koedoe.v53i2.1011.

Radloff, F. G. T., \& Du Toit, J. T. (2004). Large predators and their prey in a southern African savanna: A predator's size determines its prey size range. Journal of Animal Ecology, 73, 410-423.

Roux, D.J., \& Foxcroft, L.C. (2011). The development and application of strategic adaptive management within South African National Parks. Koedoe, 53(2), Art. \#1049, 5 pages. doi:10.4102/koedoe.v53i2. 1049.

Roux, D. J., Kingsford, R. T., McCool, S. F., McGeoch, M. A., \& Foxcroft, L. C. (2015). The role and value of conservation agency research. Environmental Management, 55, 1232-1245.

Roy, D. P., Boschetti, L., \& Trigg, S. N. (2006). Remote sensing of fire severity: Assessing the performance of the normalized burn ratio. Geoscience and Remote Sensing Letters, 3, 112-116. 
Sankaran, M., Hannan, N. P., Scholes, R. J., Ratnam, J., Augustine, D. J., Cade, B. S., et al. (2005). Determinants of woody cover in African savannas. Nature, 438, 846-849.

Scheiter, S., \& Higgins, S. I. (2009). Impacts of climate change on the vegetation of Africa: An adaptive dynamic vegetation modelling approach. Global Change Biology, 15, 2224-2246.

Scholes, R. J., \& Mennel, K. G. (2008). Elephant management: A scientific assessment for South Africa. Johannesburg: Wits University Press.

Scogings, P. F. (2011). Stem growth of woody species at the Nkuhlu exclosures, Kruger National Park: 2006-2010. Koedoe, 53(1), Art. \#1035, 8 pages. doi:10.4102/koedoe.v53i1.1035.

Seydack, A. H. W., Durrheim, G., \& Louw, J. H. (2011). Spatiotemporally interactive growth dynamics in selected South African forests: Edaphoclimatic environment, crowding and climate effects. Forest Ecology and Management, 261, 1152-1169.

Shannon, G., Thaker, M., Vanak, A. T., Page, B. R., Grant, R., \& Slotow, R. (2011). Relative impacts of elephant and fire on large trees in a savanna ecosystem. Ecosystems, 14, 1372-1381.

Smit, I. P. J., Riddell, E. S., Cullum, C., \& Petersen, R. (2013). Kruger National Park research supersites: Establishing long-term research sites for crossdisciplinary, multiscaled learning. Koedoe, 55(1), Art. \#1107, 7 pages. doi:10.4102/koedoe.v55i1.1107.

Sunderland, T., Sunderland-Groves, J., Shanley, P., \& Campbell, B. (2009). Bridging the gap: How can information access and exchange between conservation biologists and field practitioners be improved for better conservation outcomes? Biotropica, 41, 549-554.

Thuiller, W., Broennimann, O., Hughes, G., Alkemade, J. R. M., Midgley, G. F., \& Corsi, F. (2006). Vulnerability of African mammals to anthropogenic climate change under conservative land transformation assumptions. Global Change Biology, 12, 424-440.

Thuiller, W., Slingsby, J. A., Privett, S. D. J., \& Cowling, R. M. (2007). Stochastic species turnover and stable coexistence in a species-rich, fire-prone plant community. PLOS ONE, 2(9), e938. doi:10.1371/ journal.pone.0000938.

van Aarde, R., \& Jackson, T. (2007). Megaparks for metapopulations: Addressing the causes of locally high elephant numbers in southern Africa. Biological Conservation, 134, 289-297.

van Daalen, J. C. (1991). Forest growth: A 35-year southern Cape study. South African Forestry Journal, 159, 1-10.

van Eck, N. J., \& Waltman, L. (2010). Software survey: VOSviewer, a computer program for bibliometric mapping. Scientometrics, 84(2), 523-538.

van Langevelde, F., van de Vijver, C. A. D. M., Kumar, L., van de Koppel, J., De Ridder, N., van Andel, J., et al. (2003). Effects of fire and herbivory on the stability of savanna ecosystems. Ecology, 84, 337-350.

van Wilgen, B. W. (1996). Management of the natural ecosystems of the Cape Peninsula: Current status and future prospects. Biodiversity and Conservation, 5, 671-684.

van Wilgen, B. W. (2009). The evolution of fire and invasive alien plant management practices in fynbos. South African Journal of Science, 105, 335-342.

van Wilgen, B. W. \& Biggs, H. C. (2011). A critical assessment of adaptive ecosystem management in a large savanna protected area in South Africa. Biological Conservation, 144, 1179-1187.

van Wilgen, N.J., Dopolo, M., Symonds, A., Vermeulen, W., Bester, E., Smith, K., \& McGeoch, M.A., (2013). An inventory of natural resources harvested from National Parks in South Africa. Koedoe, 55(1), Art. \#1096, 5 pages. doi:10.4102/koedoe.v55i1.1096.

van Wilgen, N. J., Goodall, V., Holness, S., Chown, S. L., \& McGeoch, M. A. (2015). Rising temperatures and changing rainfall patterns in South Africa's National Parks. International Journal of Climatology,. doi:10.1002/joc.4377.

van Wilgen, B. W., Govender, N., \& Biggs, H. C. (2007). The contribution of fire research to fire management: A critical review of a long-term experiment in the Kruger National Park, South Africa. International Journal of Wildland Fire, 16, 519-530.

van Wilgen, N. J., \& McGeoch, M. A. (2014). Balancing effective conservation with sustainable resource use in protected areas: Precluded by knowledge gaps. Environmental Conservation,. doi:10.1017/ S0376892914000320.

Vanak, A. T., Shannon, G., Thaker, M., Page, B., Grant, R., \& Slotow, R. (2012). Biocomplexity in large tree mortality: Interactions between elephant, fire and landscape in an African savanna. Ecography, 35, 315-321.

Walpole, M. J., \& Leader-Williams, N. (2002). Tourism and flagship species in conservation. Biodiversity and Conservation, 11, 543-547. 